\title{
SURVIVAL AND GROWTH OF BACILLUS CEREUS DURING GOUDA CHEESE
} MANUFACTURING

\author{
BY \\ GRACE TAPIWA RUKURE \\ (9819369)
}

SUBMITTED IN PARTIAL FULFILMENT OF THE REQUIREMENTS FOR THE DEGREE

MInst Agrar FOOD PROCESSING

IN THE

DEPARTMENT OF FOOD SCIENCE

FACULTY OF BIOLOGICAL AND AGRICULTURAL SCIENCES

UNIVERSITY OF PRETORIA

SOUTH AFRICA

NOVEMBER, 1999 
I declare that the dissertation herewith submitted for the degree of MInst Agrar Food Processing at the University of Pretoria, has not been submitted by me for a degree at any other university or institution of higher education. 


\section{ACKNOWLEDGEMENTS}

I wish to acknowledge the following people without whose help this project would not have been possible. The Director, Dr Stephen Chandiwana, Blair Research Institute, my supervisor Professor B.H. Bester for the supervision as well as reading and giving constructive criticism of my dissertation.

Special thanks to my husband Hopewell Rukure and my children Munopa, Munatsireyi and Munesu for the moral support. 


\section{OPSOMMING}

Titel: Oorlewing en groei van Bacillus cereus tydens Gouda-kaas vervaardiging deur

Grace T Rukure

Studieleier: Prof B. H. Bester

Department: Voedselwetenskap

Graad: $\quad$ MInst Agrar Voedselprosessering

Die hoof doelstelling van die studie was om die oorlewing en groei van Bacillus cereus te bepaal gedurende die vervaardiging van Gouda-tipe kaas. Die kaas is in 'n toetsaanleg vervaardig met melk wat vooraf kunsmatig gekontamineer is met $10^{2} \mathrm{~B}$. cereus selle per ml melk. $B$. cereus getalle is bepaal deur uitplating op $B$. cereus selektiewe medium en melksuurbakteriegetalle is bepaal op lakaat-agar en MRS-agar (Man-Rogosa-Sharpe).

Monsters vir mikrobiologiese analise is geneem van die melk voor stremming, van die wrongel gedurende die snyproses, by die stadium waar die helfte van die wei verwyder is, by die finale weiverwydering, toe die wrongel in die vorms geplaas is, van die kaas na samepersing en na insouting, na 1 week, na 2 weke, na 4 weke en na 6 weke. Chemiese analise is na 6 weke op die kaas gedoen.

B. cereus spore is geaktiveer deur pasteurisasie by $63^{\circ} \mathrm{C}$ vir $30 \mathrm{~min}$. Hulle het ontkiem en die vegetatiewe selle het gegroei gedurende die vervaardigingsproses en het maksimum waardes van ongeveer $10^{4}$ kve per gram wrongel bereik by die vorming-stadium (ongeveer $3,5 \mathrm{~h}$ na stremming). Na samepersing (ongeveer $16 \mathrm{~h}$ na strem) het die lewensvatbare selle verminder na minder as $1 \times 10^{1} \mathrm{kve} / \mathrm{g}$. Na insouting ( $40 \mathrm{~h}$ na stremming) kon geen $B$. cereus opgespoor word nie. Op hierdie stadium het die kondisies in die kaas, veral die verlaagde voginhoud en

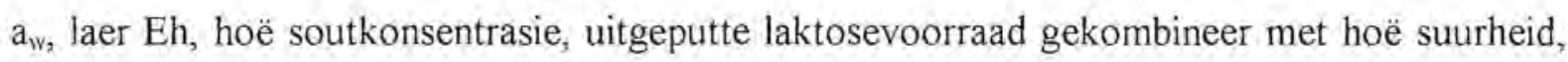
die groei van B. cereus geïnhibeer. B. cereus het geen effek gehad op die groei van melksuurbakterieë gedurende die kaasvervaardingsproses nie. Melksuurbakterieë het vermeerder van $10^{7}$ tot $10^{9}$ kve per gram wrongel gedurende die kaasvervaardigisngproses en het vir 6 weke redelik konstant gebly op $10^{9} \mathrm{kve} / \mathrm{g}$. 


\begin{abstract}
Title: Survival and growth of Bacillus cereus during Gouda cheese manufacturing by

Grace T Rukure

Study Leader: Prof. B. H. Bester

Department: Department of Food Science

Degree: $\quad$ MInst Agrar Food Processing

The primary objective of this study was to determine the survival and growth of $B$. cereus during manufacturing of Gouda type cheese. The cheese was prepared in the pilot plant from pasteurised milk artificially contaminated with $B$. cereus spores to give a final concentration of $10^{2}$ B. cereus spores per $\mathrm{ml}$ of cheese milk. B. cereus was enumerated by surface plating on B.cereus selective media and lactic acid bacteria were enumerated on lactic agar and MRS agar (Man-Rogosa-Sharpe). Samples were taken for microbiological analysis of the milk before renneting, curd at cutting, at half whey removal, at final whey removal, at hooping of the curd, the cheese after pressing, after brining, after 1 week, after 2 weeks, after 4 weeks and after 6 weeks. Chemical analysis were done on cheese after 6 weeks.
\end{abstract}

Spores of $B$. cereus were activated by pasteurisation at $63^{\circ} \mathrm{C}$ for $30 \mathrm{~min}$. The spores germinated into vegetative cells which grew and reached a maximum of approximately $10^{4}$ $\mathrm{cfu} / \mathrm{g}$ at the hooping stage (about $3,5 \mathrm{~h}$ after renneting). After pressing (approximately $16 \mathrm{~h}$ after renneting) the viable cells were reduced to less than $1 \times 10^{1}$ cfu per gram. After brining (40 h after renneting) B. cereus was not detected. At this stage the conditions of the cheese, particularly lower moisture content and $\mathrm{a}_{\mathrm{w},}$ lower $\mathrm{Eh}$, high salt content, depleted lactose content combined with high acidity inhibited the growth of $B$, cereus. $B$, cereus did not affect the growth of lactic acid bacteria during cheese manufacturing. Lactic acid bacteria grew from $10^{7}$ to $10^{9}$ cfu per gram of curd during cheese manufacturing and stayed fairly constant at about $10^{9}$ for 6 weeks. 


\section{TABLE OF CONTENTS}

PAGE

List of figures

(iv)

List of tables

1 Introduction 1

1.1 Statement of the problem 2

1.2 Objectives 3

2. Literature review 4

2.1 Bacillus cereus 4

2.1.1 Occurrence 4

2.1.2 General characteristics 5

2.1.2.1 Morphological and biochemical characteristics 5

2.1.2.2 Isolation and identification of B. cereus $\quad 7$

2.1.2.3 Heat resistance of $B$. cereus spores 7

2.1.2,4 Germination and growth of $B$. cereus $\quad 8$

2.1,2.5 Effect of heating on spore germination 9

2.1.2.6 Effect of source on germination of $B$. cereus spores 11

$\begin{array}{lll}2.1 .3 & \text { Toxin production } & 11\end{array}$

2,1.3.1 Haemolysin 13

2.1.3.2 Phosholipase C 13

2.1.3.3 Diarrheal toxin $\quad 14$

2.1.3.4 Emetic toxin $\quad 14$

2.1.3.5 Comparison of emetic and diarrheal type strains $\quad 14$

2.1.4 Toxin detection methods 15

2.1.5 Public health problems 16

2.1.6 Prevention of growth of B. cereus 17

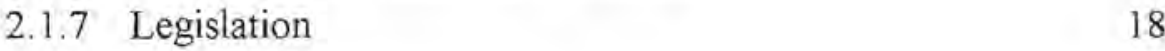

$\begin{array}{lll}2.2 & \text { Starter cultures } & 18\end{array}$

2,2.1 Classification of dairy starter cultures $\quad 19$

(i) 
2.2.2 Fermentation of lactose by lactic acid bacteria (LAB) 23

2.2.3 Factors affecting growth of starter cultures 24

2.2.4 Effect of lactic acid bacteria on survival and growth of B. cereus $\quad 26$

2.2.5 Antimicrobial substances produced by lactic acid bacteria 27 2.2.5.1 Hydrogen peroxide 28

2.2.5.2 Diacetyl 29

$\begin{array}{ll}2.2 .5 .3 \text { Bacteriocins } & 29\end{array}$

2.3 Gouda cheese manufacturing 30

2.3.1 Overview of Gouda cheese manufacture $\quad 30$

2.3.2 Basic steps in the manufacture of Gouda cheese 31

2.3.2.1 Coagulation (Curd formation) 32

2.3.2.2 Cooking (scalding) and whey removal $\quad 32$

2.3 .2 .3 Salting $\quad 33$

2.3.2.4 Ripening $\quad 33$

2.4 Nutritional aspects of the cheese 34

3 Materials and methods 36

3.1 Manufacturing of Gouda cheese $\quad 36$

3.1.1 The milk 36

3.1.2 The starter culture $\quad 36$

3.1.2.1 Mother cultures $\quad 36$

3.1.2.2 Bulk cultures $\quad 36$

3.1.3 Manufacturing of the cheese 37

3.2 Preparation of $B$. cereus spore suspensions $\quad 37$

3.2.1 Growth and sporulation of the cultures 37

3.2.2 Harvesting of the spores $\quad 38$

3.3 Survival and growth of $B$. cereus during Gouda cheese manufacturing 38

3.3.1 Experimental design 38

3.3.2 Sampling $\quad 39$

(ii) 
3.4 Microbiological analyses $\quad 40$

3.4.1 Preparation of dilutions $\quad 40$

3.4.2 Plate-counts by spread-plate technique $\quad 40$

3.4 .3 B. cereus counts $\quad 40$

3.4.4 Lactic acid bacteria $\quad 41$

3.5 Chemical analyses 41

$3.5 .1 \mathrm{pH} \quad 41$

3.5.2 Titratable acidity 41

3.5.3 Fat content of milk $\quad 42$

3.5.4 Fat content of cheese $\quad 42$

3.5.5 Salt content of cheese $\quad 42$

3.5.6 Moisture content $\quad 42$

3.6 Statistical analyses $\quad 42$

4. Results 43

4.1 Changes in $B$, cereus and lactic acid bacteria numbers during the cheese manufacturing

4.2 Changes in $\mathrm{pH}$, B. cereus and lactic acid bacteria numbers during cheese manufacturing $\quad 45$

4.3 Chemical analyses of the cheese at 6 weeks 50

5 Discussion $\quad 52$

6 Conclusion and recommendations 55

$\begin{array}{ll}\text { References } & 57\end{array}$

$\begin{array}{ll}\text { Appendix } & 67\end{array}$ 


\section{LIST OF FIGURES}

Figure 1. The different layers of B. cereus spores (Andersson, Ronner \& Granum, 1995)

Figure 2. Germination of spores of $B$. cereus T16 previously activated in water at $75^{\circ} \mathrm{C}$ for 30 min and then pasteurised in milk for 15 s over a range of temperatures (Davies \& Wilkinson, 1973)

Figure 3. Classification and differentiation of dairy starter cultures (Tamime, 1981)

Figure 4. Generalised pathways for the production of some fermentation products from glucose by: 1A Homofermentative lactics; IB:Heterofermentative lactics (Jay, 1992) 24

Figure 5. Growth of Bacillus cereus artificially inoculated in three types of cheeses: type A, type B and type C (Lodi \& Malaspina,1992).

Figure 6. Mechanisms of hydrogen peroxide generation by lactic acid bacteria (Daeschel, 1989)

Figure 7. Flow diagram for cheese manufacture.

Figure 8. Changes in B. cereus and lactic acid bacteria numbers during Gouda type cheese manufacturing from milk inoculated with B. cereus spores. 
Figure 9. Changes in $\mathrm{pH}$, numbers of lactic acid bacteria and $B$. cereus during manufacture of Gouda type cheese from milk inoculated with $B$. cereus spores

Figure 10. Changes in $\mathrm{pH}$ and numbers of lactic acid bacteria during manufacturing of control Gouda type cheese (milk not inoculated with $B$. cereus)

Figure 11. Colony morphology of $B$. cereus colonies grown on $B$. cereus selective agar 


\section{LIST OF TABLES}

Table 1. Thermal resistance data for spores of selected psychrotrophic bacilli (Meer, Baker, Bodyfelt \& Griffiths, 1991) 8

Table 2. Growth parameters of Bacillus spp. grown in milk (Meer et al, 1991) 9

Table 3. The toxins of Bacillus cereus (Granum, 1994) 12

Table 4. Examples of food poisoning outbreaks where $B$. cereus was the probable etiological agent (Kramer \& Gilbert, 1989). 16

Table 5. Occurrence of $B$. cereus in milk and dairy products manufactured in Victoria (Rangasamy, Iyer \& Roginski, 1994).

Table 6. Lactic acid bacteria employed as starter cultures for cheese-making (Tamime, 1981)

Table 7. Factors responsible for inhibition of starter cultures (Rosenthal, 1991). 25

Table 8. Nutrients of cheese per $100 \mathrm{~g}$ (adapted from Scott, 1986), 35

Table 9. Sampling plan during Gouda cheese manufacturing showing process steps and stages at which samples were drawn for microbiological and chemical analyses. 39

Table 10. Changes in B. cereus and lactic acid bacteria numbers during the manufacturing of Gouda cheese 
Table 11. Changes in $\mathrm{pH}$, numbers of lactic acid bacteria ( $\mathrm{AAB}$ ) and $B$. cerens during manufacturing of Gouda type cheese from milk inoculated with B. cereus spores

Table 12. Changes in $\mathrm{pH}$ and numbers of lactic acid bacteria during manufacture of control Gouda type cheese (no B. cerens spores added)

Table 13. Means of $\mathrm{pH}, \%$ salt content, moisture content and $\%$ fat content of the experimental and control cheese at 6 weeks 


\section{CHAPTER 1}

\section{INTRODUCTION}

Gouda is a semi-hard cheese variety made from cow's milk and originated from Holland (Kosikowski, 1978). Milk used for cheese-making should be of a good bacteriological quality to avoid undesirable fermentation and enzymic reactions and without any substances that inhibit or interfere with the growth of the starter bacteria (Chapman \& Sharpe, 1981). Milk is an excellent medium for microbial growth. Milk as produced in the alveoli of a healthy cow is free from microorganisms, but the farm environment makes it impossible to exclude bacteria during milking (Andersson, Ronner \& Granum, 1995). The bacterial load of raw milk ranges from $10^{3}$ per $\mathrm{ml}$ when hygiene is good, to $10^{7}$ per $\mathrm{ml}$ when hygiene is poor (Chapman \& Sharpe, 1981). The bacteria consist of psychrotrophs, small numbers of lactic acid bacteria, spore forming Gram-positive rods, coryneform bacteria, micrococci and coliforms (Chapman \& Sharpe, 1981). Psychrotrophs will continue to multiply during transport and storage of milk. Pasteurisation $\left(72^{\circ} \mathrm{C}\right.$ for $\left.15 \mathrm{~s}\right)$ of the milk prior to Gouda cheese manufacture will reduce the microbial load, but the thermoduric microorganisms with psychrotrophic properties survive (Andersson et al, 1995) and of importance to this research are the species Bacillus cereus.

Occurrence of $B$. cereus in milk has been reported since 1916, and this bacterium is a common contaminant of raw milk produced on some dairy farms (Ahmed, Moustafa \& March, 1983). It can also be found in large numbers in dairy products (Ahmed et al, 1983). In a survey by Wong, Chen $\&$ Chen (1988) on dairy products, $52 \%$ of ice creams, $35 \%$ of soft ice creams, $29 \%$ of milk powders, $17 \%$ of fermented milks, and $2 \%$ of pasteurised milks and fruit flavoured milks were found to be contaminated with $B$. cereus. The concern about it's presence in dairy products is that it may cause certain defects in the products or produce toxins and thus cause food poisoning.

At counts above $2 \times 10^{5} / \mathrm{ml} \mathrm{B}$. cereus causes off flavours such as unclean, fruity, bitter, putrid, rancid and yeasty (Meer, Baker, Bodyfelt \& Griffiths, 1991). When growth continues, the product shows the defect sweet curdling in homogenised low-pasteurised 
milk and bitty cream in low-temperature pasteurised milk. It has been estimated that more than $25 \%$ of the shelf-life problems encountered with pasteurised milk are due to the proliferation of Bacillus species (Griffiths, 1992). Although low numbers of B. cereus in foods pose no direct health hazard, if these foods are mishandled, growth of this organism might result in a direct health hazard. Large numbers of $B$. cereus produce enterotoxin in the food before it is consumed and cause illness (Macrae, Robinson \& Sadler, 1993).

There are two types of food poisonings caused by B.cereus, namely the emetic and the diarrheal type (Wong et al,1988; In't Veld, Soentaro \& Notermans, 1993; Granum, 1994). A large number of viable cells of $B$. cereus is required to cause illness; numbers in excess of $10^{5}-10^{6}$ per gram have been encountered in food suspected of causing illness (Ahmed et al, 1983). Foodborne illness caused by B. cereus is considered as a food intoxication rather than a food infection, so a significant level of growth by the organism would be required to synthesize the necessary level of extracellular toxin (Ahmed et al, 1983).

The objective of this study was to determine the survival and growth of B.cereus during manufacture of Gouda type cheese.

\subsection{Statement of the problem}

Under modern processing conditions, milk and milk products can be successfully kept almost free from contamination after pasteurisation. Although this has significantly improved the keeping quality of packed products in general, micro-organisms surviving pasteurisation now determine the keeping quality of the products. An example of such a thermoduric micro-organism is $B$. cereus which has been found to be more difficult to control in the dairy industry. Apart from it's presence in almost all milk received at dairy factories, it's spores are very hydrophobic and will attach to the surfaces of the pipelines in dairy plants, where they can multiply quite rapidly and even sporulate (Andersson et al, 1995). Since the spores survive pasteurisation, B. cereus is often setting the limits of keeping quality of milk and milk products. Apart from its role in the spoilage of heattreated milk and several other dairy products, the production of toxins by some strains pose a risk to the safety of dairy products. 


\subsection{Objectives of the project}

A considerable amount of research has been carried out on the growth and survival of $B$. cereus in milk and during yoghurt manufacture (Wong \& Chen, 1988; Driessen, 1992) but little if any research has been done on growth of $B$. cereus during Gouda cheese manufacturing.

\section{The primary objective of the project was}

To determine the growth and survival of B.cereus during manufacture of Gouda type cheese.

\section{The secondary objectives were}

To determine whether B. cereus would affect the growth of lactic acid bacteria during Gouda cheese manufacturing. 


\section{CHAPTER 2}

\section{LITERATURE REVIEW}

\subsection{BACILLUS CEREUS}

\subsubsection{Occurrence}

B. cereus is impossible to eliminate in the food industry and has been found to be associated with various forms of food spoilage and food poisoning (Kramer \& Gilbert, 1989). It can be introduced into milk supplies from water, udder and teat surfaces, or from soil and milk stone deposits, gaskets and processing equipment (Meer et al, 1991; Kalogoridou-Vassiladou \& Tsiantas, 1992). Soil has been shown to contain $10^{5}-10^{6}$ spores per gram (Andersson et al, 1995). B. cereus may also be isolated from rice, dairy products, meat, spices and eggs (Kramer \& Gilbert, 1989). The bacterium survives different environmental stresses which makes it very difficult for the food industry to exclude $B$. cereus from their products.

Milk was known to be contaminated with B. cereus before the organism's pathogenicity was established (Johnson, 1984). It causes a defect known as "bitty" cream or sweet curdling of milk (Overcast \& Atmaram, 1974; Johnson, 1984), the source of the milk contamination having been traced to mastitic cows and to cans of milk that were allowed to stand after emptying (Johnson, 1984). Spores of B. cereus may occasionally survive UHT treatment and may be one of the main spoilage organisms if the milk is not recontaminated after pasteurisation (Stadhouders \& Beumer, 1993). B. cereus has also been reported to cause defects in yoghurt (Driessen, 1992). According to Driessen (1992) all spores of B. cereus found in milk products originated from raw milk, contamination with spores was higher in winter than in late summer. Davies \& Wilkinson (1973) have pointed out that "new" products such as puddings, presumably the shelf stable variety, may present problems with $B$. cereus. Outbreaks of foodborne illnes involving vanilla slices and macaroni and cheese dishes were thought to have been caused by contamination from the milk powder used in their preparation (Jonhson, 1984). 
Bacillus spp. comprised $90 \%$ of rice paddy soil bacteria (Asanuma, Takana \& Yatazawa, 1979). The high association of the emetic syndrome with rice dishes is thus not surprising since $B$. cereus is usually present in rice. The organism has also been isolated from other Oriental dishes and ingredients, such as egg rolls and vegetables (Sly \& Ross, 1982) and therefore rice should not be viewed as the only potential contributor to diarrheal toxins in Oriental foods.

Dried products like legumes have also been shown to be contaminated with $B$. cereus. The organism has been isolated from cooked Mexican-style beans (Johnson, 1984). Blakey \& Priest (1980), pointed out the potential hazard of soaking dried legumes before cooking. This practice is necessary for a satisfactory product; however, growth of indigenous $B$. cereus does occur and numbers can reach hazardous levels. Numerous spices have been shown to contain $B$. cereus and it has been reported that heavy use of spices in Hungarian cooking may have contributed to the high reported incidence of $B$. cereus illness outbreaks in that country (Johnson, 1984). Garlic extracts, however, have been shown to inhibit growth of B. cereus (Johnson, 1984).

\subsubsection{General characteristics}

Certainly a major concern to food microbiologists is the destruction of microorganisms. As B. cereus forms spores most of the concern revolves about destruction of the spores rather than the vegetative cells.

\subsubsection{Morphological and biochemical characteristics}

B. cereus is classified in the family Bacillaceae. Cells are large rods $(0,5-2,5 \times 1,2-10,0$ $\mu \mathrm{m}$ ) with rounded or squared ends and are often arranged in pairs or chains (Stanier, Adelberg \& Ingraham, 1979). B. cereus cells are Gram-positive and motile by peritrichous flagella (Frankland \& Frankland, 1974). The spores are very hydrophobic and they have a suitable spore morphology which makes them easily attach to pipes and surfaces (Andersson et al, 1995). The spores are covered with long appendages (Figure 1) which promotes adhesion and this compounds the problem of contamination from equipment and utensils. 


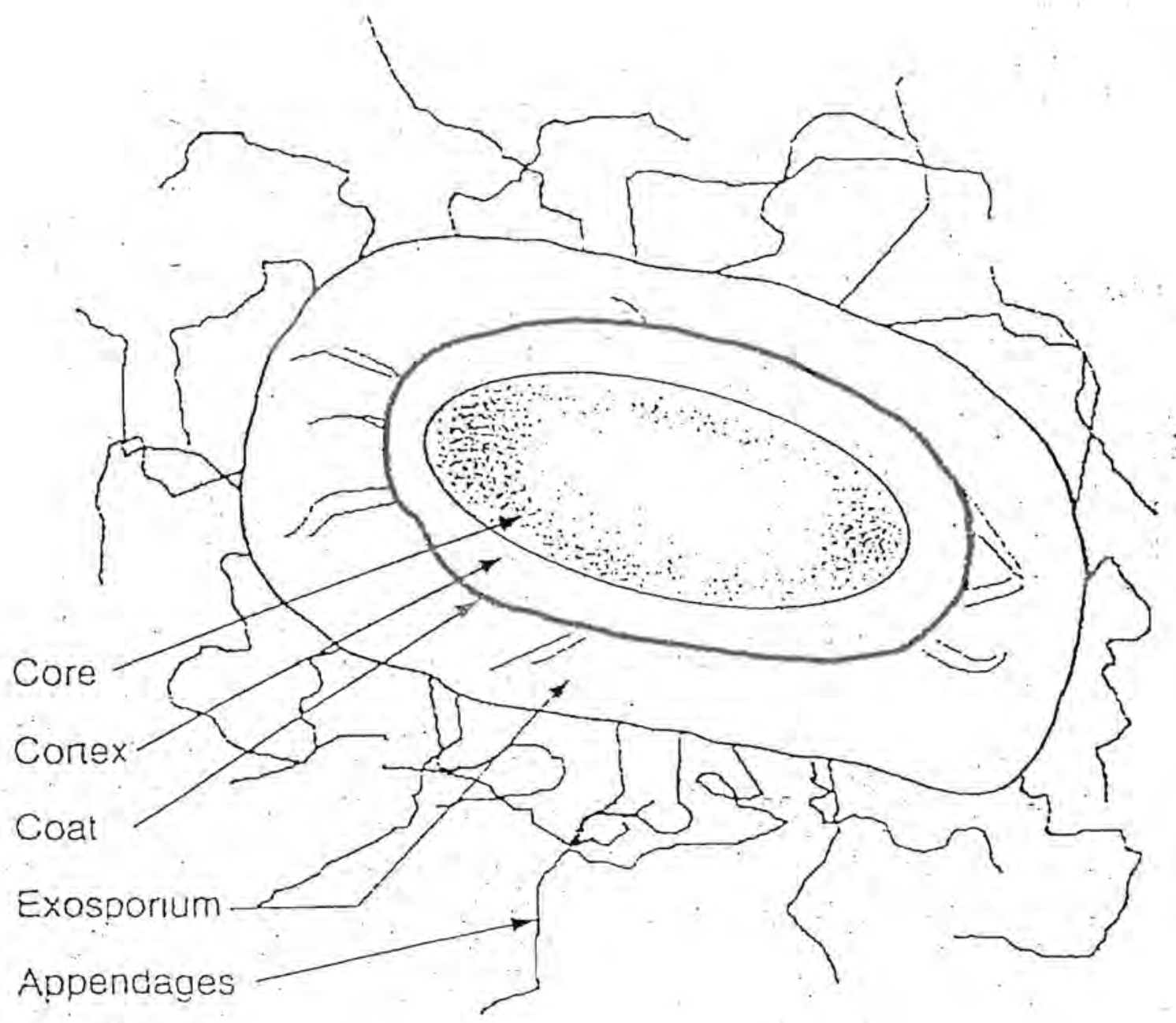

Figure 1 Tlie different layers of $B$. cereus spores (Andersson et al, 1yys)

Growth has been demonstrated over the pH range 4.9 to 9.3 (Jay, 1992). Bacillus cereus can grow at minimum temperatures of $4-5^{\circ} \mathrm{C}$ and maximum temperatures of $48-50^{\circ} \mathrm{C}$. It grows well on $B$. cereus selective agar containing egg yolk emulsion and forms rough, dry colonies with a ring of dense precipitate (Mossel, Koopman \& Jongerius, 1967). B. cereus is catalase positive, ferments glucose with the production of 2,3-butanediol, glycerol and carbon dioxide (Frankland \& Frankland, 1974: Stanier et al, 1979). Fermentation can be represented as: 
B. cereus reduces nitrate to nitrite and is lecithinase positive, It does not ferment mannitol, xylose or arabinose. It has been shown to be inhibited by high levels of spoilage microorganisms, nisin, $0.02 \%$ sorbic acid and $0.40 \%$ potassium sorbate (Steele \& Stiles, 1981). Antibiotics effective against B.cereus are aureomycin, dihydrostreptomycin, terramycin, bacitracin, oxytetracycline, chloramphenicol, and gentamycin (Johnson, 1984). Slight inhibition was observed with neomycin, cloxacillin, ampicillin and penicillin but there was no inhibition of B. cereus by polymyxin (Johnson, 1984)

\subsubsection{Isolation and identification of B.cereus}

Isolation of $B$. cereus from food involves plating on differential and selective media. The most commonly used media formulation include: mannitol-egg yolk-polymyxin (MYP) agar, KG agar, blood agar, polymyxin-pyruvate-egg yolk mannitol bromothymol blue agar (PEMBA) (Meer et al, 1991). Several of these formulas use polymyxin as an inhibitory agent for competitive organisms and are designed to use the mannitol negative, lecithin hydrolyzing nature of $B$. cereus for differentiation. Typical B. cereus colonies on PEMBA plates are peacock blue with a surrounding zone of precipitation, while colonies on the plates that contain bromocresol purple are mauve in color with a zone of precipitation (Szabo, Todd \& Rayman, 1984).

\subsubsection{Heat resistance of $B$. cereus spores}

Various theories have been proposed for the physiological mechanism for heat resistance, including several mechanisms based on partial dehydration, hydrostatic pressure applied to the protoplast by the cortex and an expansive cortex (Johnson, Nelson \& Busta, 1982; Marquis, Sim \& Shin, 1994). Shehata \& Collins (1972) measured the heat resistance in sterilised milk of psychrotrophic spores which had been isolated from pasteurised milk (Table 1). 
Table 1 Thermal resistance data for spores of selected psychrotrophic bacilli

(Meer et al, 1991)

\begin{tabular}{|lccccc|}
\hline \multirow{2}{*}{ Organism } & \multicolumn{5}{c|}{ D-Value at } \\
\cline { 2 - 5 } & $85^{\circ} \mathrm{C}$ & $90^{\circ} \mathrm{C}$ & $92.5^{\circ} \mathrm{C}$ & $95^{\circ} \mathrm{C}$ & z-value \\
B. cereus & 18.5 & 5.8 & 3.4 & 1.8 & 9.4 \\
B. pumilus & 16.5 & 5.1 & 2.7 & 1.4 & 9.7 \\
B. laterosporus & 20.5 & 6.5 & 3.9 & 2.1 & 10.1 \\
Bacillus DPL & 18.9 & 6.6 & 4.2 & 2.4 & 11.0 \\
\hline
\end{tabular}

D-values at $90^{\circ} \mathrm{C}$ varied between 5.1 and $6.6 \mathrm{~min}$. Meer et al (1991) reported that D-values for $B$. cereus strains isolated from a number of dairy products were in the range of 2 to 5.4 min at $90^{\circ} \mathrm{C}$. The heat resistance of Bacillus spores may be affected by the composition of the suspending media (Shehata \& Collins, 1972). In particular lipids have been shown to confer a protective effect on spores (Meer et al, 1991).

\subsubsection{Germination and growth of $B$. cereus}

Most of $B$. cereus and related species isolated from dairy products were able to grow below $10^{\circ} \mathrm{C}$ but strains from the dairy environment and from paperboard mills had higher minimum growth temperatures. According to Meer et al (1991), the conceptional minimum growth temperature for $B$. cereus averaged $15^{\circ} \mathrm{C}$. There was a correlation between minimum growth temperature and fatty acid composition of B. cereus.

Milk contains bacterial spores that exhibit a range of genetically predetermined germination rates (Meer et al, 1991). These can be differentiated into fast, intermediate and slow germinating types. It has been shown that a factor is present in milk that promotes germination of $B$. cereus (Meer et al, 1991). The germination factor was thought to be an organic compound with a molecular weight below $200 \mathrm{kDa}$ and which was active at concentrations of $10 \mu \mathrm{g} / \mathrm{ml}$ or less. There is evidence that the germinant was associated with small peptides and may in fact be hippuric acid. 
According to Chung \& Cannon (1971), strains of psychrotrophic Bacillus species examined had a lag phase of 8 to $14 \mathrm{~d}$ and a generation time of 22 to $26 \mathrm{~h}$ at $7^{\circ} \mathrm{C}$. Typical growth parameters for psychrotrophic bacilli isolated from dairy products are shown in Table 2.

Table 2 Growth parameters of Bacillus spp. grown in milk (Meer et al, 1991)

\begin{tabular}{|lcccccc|}
\hline & \multicolumn{7}{c|}{ Temperature of growth } \\
\cline { 2 - 7 } Species & \multicolumn{7}{c|}{$2^{\circ} \mathrm{C}$} & \multicolumn{3}{c}{$10^{\circ} \mathrm{C}$} \\
\cline { 2 - 7 } Bag $^{\circ}$ cereus $^{c}$ & $\mathrm{NG}^{\mathrm{d}}$ & $\mathrm{NG}$ & 78 & 17 & Lag & Gen \\
B. circulans $^{\mathrm{b}}$ & 60 & 28 & 33 & 11 & 31 & 4 \\
B. mycoides $^{\mathrm{b}}$ & $\mathrm{NG}$ & $\mathrm{NG}$ & 92 & 22 & 33 & 4 \\
\hline
\end{tabular}

2. Lag time in $\mathrm{h}$

b. Generation time in h.

c Mean for four strains

d No growth after $21 \mathrm{~d}$ incubation

e Mean of four strains

i Mean for two strains

\subsubsection{Effect of heating on spore germination}

Heating influences germination in two ways. Firstly, by a direct effect upon the spore and secondly by affecting the medium within which the spore may germinate. The first of these concerns the activation temperature. It has long been known that the germination of most spores is activated by a period of sub-lethal heat treatment (Setlow, 1994). Davies \& Wilkinson (1973) reported that little activation of the spores occurred at the normal pasteurisation temperature $\left(71,7^{\circ} \mathrm{C}\right.$ for $\left.15 \mathrm{~s}\right)$ used for commercial pasteurisation. However an elevation of this temperature significantly increased the level of germination. The spores survived pasteurisation temperatures of $80^{\circ} \mathrm{C}$ for $10 \mathrm{~min}$ (Stone \& Rowlands 1952). Figure 2 shows that for pasteurisation temperatures above $55^{\circ} \mathrm{C}$ the extent of germination of spores activated at $75^{\circ} \mathrm{C}$ for 30 min increased markedly to a maximum at $65-75^{\circ} \mathrm{C}$, a range within which the temperature for commercial HTST pasteurisation unfortunately falls (Davies \& Wilkinson, 1973). 


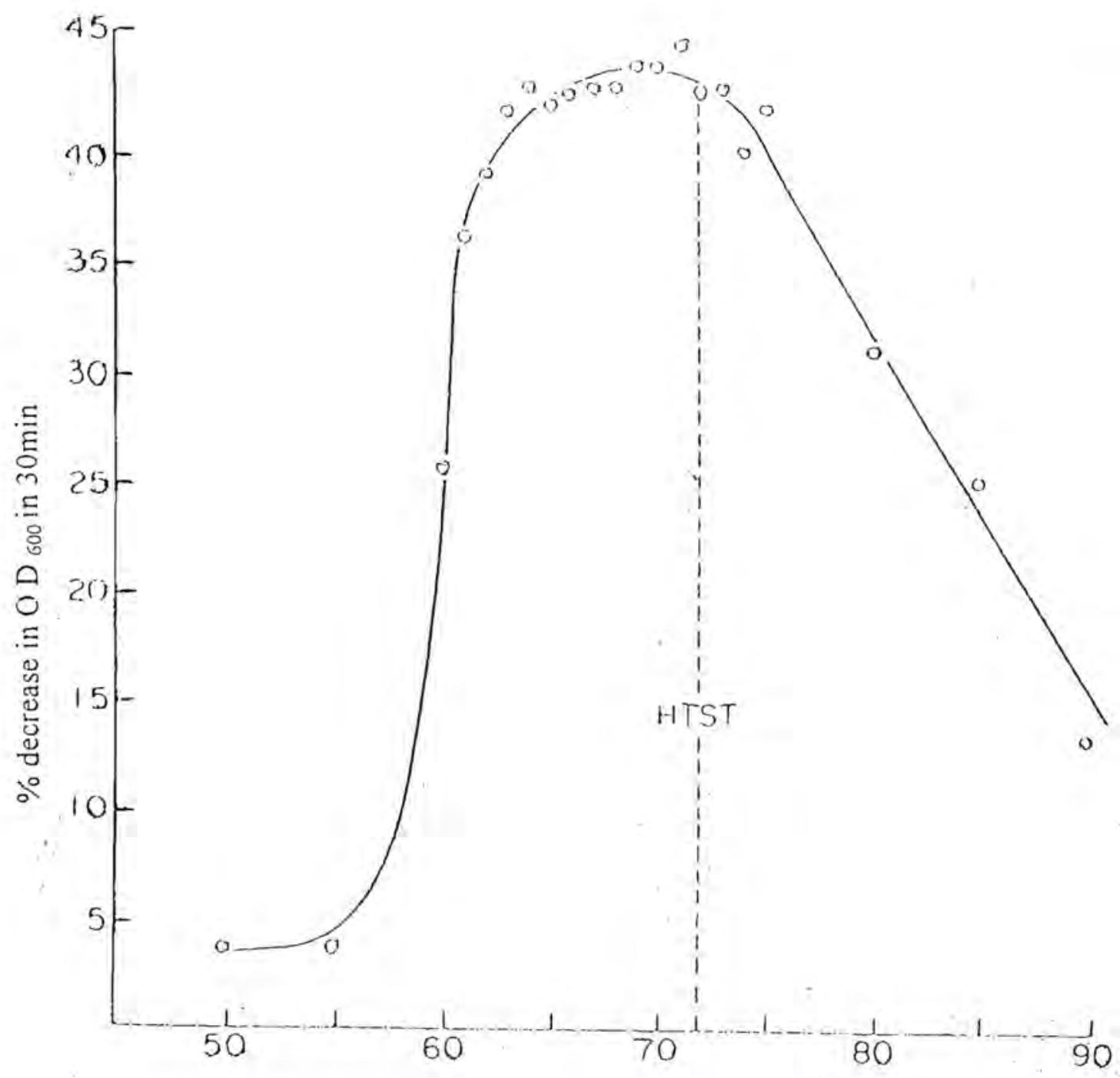

Pasteurisation temperature

Figure 2 Germination of spores of $B$. cereus T16 previously activated in water at $75^{\circ} \mathrm{C}$ for 30 min and then pasteurised in milk for $15 \mathrm{~s}$ over a range of temperatures (Davies \& Wilkinson, 1973) 


\subsubsection{Effect of source on germination of B.cereus spores}

Meer et al (1991) reported that the rate at which bacterial spores germinated depended on their specific source. For instance spores isolated from soil and faeces tended to be fast germinators, while those isolated from raw milk and soiled milking equipment appeared to be slower germinators. Davies (1977) suggested that large numbers of B. cereus spores in pasteurised milk can be derived as dairy processing plant contaminants, rather than the common assumption that spores are always introduced at the dairy farm. Davies (1977) also noted that $B$. cereus spores isolated from raw milk were slower germinators than isolates from pasteurised milk. This could be indicative that $B$. cereus isolates from pasteurised milk were most likely derived from the dairy plant (i.e. post process contaminants),

\subsubsection{Toxin production}

$B$. cereus produces seven types of toxins which can be divided into four groups of toxins namely enterotoxins, haemolysins, phospholipase $\mathrm{C}$ and emetic toxin (Table 3). Six of these toxins are produced and secreted by cells during vegetative growth. The seventh toxin is the emetic toxin which is most probably produced from components in foods during growth of $B$ cereus. According to In't Veld et al, (1993) and Granum (1994), B. cereus is known to cause two distinct food-borne illness syndromes, one is caused by diarrhoeal toxins, while the other is characterised by the emetic toxins. 
Table 3 The toxins of Bacillus cereus (Granum, 1994)

\begin{tabular}{|c|c|c|c|}
\hline Toxin & $\begin{array}{l}\text { Molecular weight } \\
\text { (mature molecule) }\end{array}$ & Signal peptide size & Characteristics \\
\hline Enterotoxin & $\approx 40 \mathrm{kDa}$ & Not detected & $\begin{array}{l}\text { Membrane damage, } \\
\text { heat labile, } \\
\text { susceptible to } \\
\text { proteolysis }\end{array}$ \\
\hline $\begin{array}{l}\text { Haemolysins } \\
\text { Cereolysin }\end{array}$ & $\approx 56 \mathrm{kDa}$ & Not detected & $\begin{array}{l}\text { Thiol activated, heat } \\
\text { labile, little } \\
\text { susceptible to } \\
\text { proteoloysis }\end{array}$ \\
\hline Haemolysin II & $\approx 30 \mathrm{kDa}$ & Not detected & $\begin{array}{l}\text { Heat labile, } \\
\text { susceptible to } \\
\text { proteolysis }\end{array}$ \\
\hline Sphingomyelinase & $34 \mathrm{kDa}$ & 27 amino acids & $\begin{array}{l}\text { Stable matallo- } \\
\text { enzyme }\left(\mathrm{Mg}^{2+}\right) \text {, } \\
\text { heamolysin }\end{array}$ \\
\hline $\begin{array}{l}\text { Phospholipase C } \\
\text { Phosphatidvlinositol } \\
\text { hydrolase (PIH) }\end{array}$ & $34 \mathrm{kDa}$ & 31 amino acids & $\begin{array}{l}\text { Non-metallo enzyme, } \\
\text { sequence homology } \\
\text { to other pro- and } \\
\text { eukaryotic enzymes }\end{array}$ \\
\hline $\begin{array}{l}\text { Phosphatidylcholine } \\
\text { hydrolase }(\mathrm{PCH})\end{array}$ & $27 \mathrm{kDa}$ & 38 amino acids & $\begin{array}{l}\text { Stable metallo- } \\
\text { enzyme }\left(\mathrm{Zn}^{2+}, \mathrm{Ca}^{2+}\right)\end{array}$ \\
\hline Emetic toxin & $5-7 \mathrm{kDa}$ & Not detected & $\begin{array}{l}\text { Heat stable to } 121^{\circ} \mathrm{C} \text {, } \\
\text { non-metabolic } \\
\text { product, lipid (?) }\end{array}$ \\
\hline
\end{tabular}




\subsubsection{Haemolysin}

Three different haemolysins are known from $B$. cereus and have been characterised quite well. The cereolysin is a thiol activated protein that cross-react with streptolysin-O and has a calculated molecular weight of about $55 \mathrm{kDa}$ (518 amino acids) (Granum, 1994). It is heat labile but relatively little susceptible to proteolysis (Granum, 1994). It is responsible for the main haemolysis of $B$. cereus, is lethal when injected in mice and is inhibited by cholesterol and serum. The secondary haemolysin has a molecular weight of about $30 \mathrm{kDa}$, is heat labile and is easily degraded by proteolytic enzymes (Granum, 1994). It is not inhibited by cholesterol.

Sphingomyelinase is well characterised and is most probably responsible for heat stable haemolysis (Tomita, Taguchi \& Ikezawa, 1991). It is a metallo-enzyme $\left(\mathrm{Mg}^{2+}\right)$ and works best as a haemolysin through the so-called hot-cold incubation $\left(37-4^{\circ} \mathrm{C}\right)(\mathrm{Granum}, 1994)$.

\subsubsection{Phospholipase C}

Bacillus cereus produces three different types of phospholipase C (Granum, 1994). They have all been cloned and are well characterised. Phosphatidylinositol hydrolyse (PIH) is a protein that specifically hydrolyse phosphatidylinositol (PI) and PI-glycan containing membrane anchors, which are important structural components of one class of membrane proteins. The enzyme is synthesized as a 329 amino acids protein with a signal peptide of 31 amino acids resulting in a mature enzyme of about $34 \mathrm{kDa}$ (Granum, 1994).

Phospatidylcholine hydrolase (PCH) hydrolyses phosphatidylcholine, phosphatidylethanolamine and phosphatidylserine (Granum, 1994). $\mathrm{PCH}$ is synthesized as a 283 amino acid protein leaving 245 amino acids in the mature protein.

Sphingomyelinase (SM) is larger with 333 and 306 amino acids in the synthesized and mature protein respectively. It needs $\mathrm{Mg}^{2+}$ and is inhibited by $\mathrm{Zn}^{2+}$ and $\mathrm{Ca}^{2+}$. 


\subsubsection{Diarrheal toxin}

The diarrheal toxin is heat labile and sensitive to trypsin and ponase (Jay, 1992). It is produced over a $\mathrm{pH}$ range of 6,0 to 8,5 . Growth and toxin production have been demonstrated at $4^{\circ} \mathrm{C}$ (Jay, 1992). The syndrome is mild and it develops within 8 to $16 \mathrm{~h}$ and lasts for 6 to $12 \mathrm{~h}$ (Jay, 1992; Granum, 1994). Symptoms consist of nausea (but vomiting is rare), cramplike abdominal pains, tenesmus and watery stool. Fever is generally absent (Jay, 1992). The symptoms of this toxin are similar to those caused by Clostridium perfrigens. The foods involved in the diarrheal illness have been quite varied, ranging from vegetables and salads to meat dishes and casseroles. The enterotoxin probably consists of three proteins (Mr 43000, 39000 and 38000 respectively). The enterotoxin is produced during the log phase of the growth cycle and it is relatively unstable to heat (destroyed at $55^{\circ} \mathrm{C}$ for $20 \mathrm{~min}$ )

\subsubsection{Emetic toxin}

The emetic toxin differs from the diarrheal toxin by being heat and $\mathrm{pH}$ stable. The toxin is sensitive to trypsin and pepsin (Jay, 1992; Granum, 1994). The emetic toxin is produced over the range 15 to $50^{\circ} \mathrm{C}$ with an optimum between 35 to $40^{\circ} \mathrm{C}$ (Jay, 1992). The enterotoxin is unstable at $\mathrm{pH}$ lower than $\mathrm{pH} 4$ and is produced in the presence or absence of oxygen. The $\mathrm{pH}$ range is pH 2-11 (Goepfert, Spira, Glatz \& Kim, 1972; Granum, 1994). Intoxication is rapid and occurs within 1-5 h, with nausea and vomiting, occasionally accompanied by diarrhea which lasts for less than $24 \mathrm{~h}$ (Granum, 1994). This form of B. cereus food poisoning is more severe and acute than the diarrheal form. The incubation period and symptoms mimic those of Staphylococcus aureus food poisoning. Illness may be due to toxin ingestion or toxin produced by ingested live cells (Granum, 1994). Emetic syndrome is often associated with fried or boiled rice dishes, pasteurised cream, spaghetti, mashed potatoes and vegetable sprouts (Jay, 1992).

The number of organisms necessary to cause illness are $2 \times 10 \%$ (Jay, 1992). The emetic toxin is a small protein $(\mathrm{Mr}<10000)$ and is stable to heating at $126^{\circ} \mathrm{C}$ for $90 \mathrm{~min}$.

\subsubsection{Comparison of emetic and diarrheal type strains}

According to Johnson (1984), there was little difference between growth rates of B. cereus strains isolated from diarrheal or emetic outbreaks, or strains naturally occurring in rice. Germination was more extensive for diarrheal strains than emetic strains in trypticase soy broth and in rice (Johnson, 1984). According to Johnson (1984), antibiotic sensitivity and fatty acid 
composition of emetic and diarrheal B. cereus were similar. Certain diarrheal strains could ferment mannose or salicin while no emetic strains had these abilities. According to Johnson (1984), the symptoms produced by the strains were related to the food involved, rather than the strain. Johnson (1984) reported that a distinction between diarrheal and emetic types could be made with an API system and numerical methods of identification. B. cereus strains isolated from food involved in food borne illness outbreaks lacked the ability to hydrolyse starch. According to Johnson (1984), there was no difference in biochemical properties, antibiotic sensitivity, cerecin production, or phage sensitivity between emetic and diarrheal types.

\subsubsection{Toxin detection methods}

Several investigators of $B$. cereus food poisoning have used various methods to detect both the diarrheal and emetic toxins. According to Meer et al (1991), a toxin detection kit based on RPLA is available to assay for $B$. cereus. The method was used to investigate three outbreaks of food intoxications caused by psychrotrophic B. cereus. The foods implicated in each outbreak were homemade vegetable pie, codfish and pasteurised milk. These outbreaks caused diarthea and abdominal cramps. The $B$. cereus isolated from the vegetable pie and codfish were positive for enterotoxin production as determined by the RPLA test kit. The outbreak involving pasteurised milk caused nausea and vomiting, but the bacilli isolated were negative for enterotoxin production as determined by the RPLA test. B. cereus was recovered from all three foods at levels of 0.2 to $0.4 \times 10^{6} \mathrm{cfu} / \mathrm{g}$. Additionally, this study reported that about $25 \%$ of psychrotrophic strains of $B$. cereus isolated from commercial pasteurised milk samples were enterotoxin positive (Meer et al, 1991)

The RPLA test kit was also used by Griffiths (1990) to determine the toxigenic activity of psychrotrophic $B$. cereus isolated from raw or pasteurised milks. Of these $B$. cereus strains, $85 \%$ demonstrated toxin production when grown in brain heart infusion (BHI) broth at $25^{\circ} \mathrm{C}$. Four strains exhibiting high levels of toxin under these growth conditions were tested for their ability to synthesize toxin in sterile reconstituted skim milk at $6,10,15$ and $21^{\circ} \mathrm{C}$. Toxin production increased with increasing temperature, but the toxin was produced during growth in milk at all temperatures under stagnant conditions. 


\subsubsection{Public health problems}

Kramer \& Gilbert (1989) summarised a number of foodborne outbreaks caused by B. cereus (Table 4).

Table 4 Examples of food poisoning outbreaks where $B$. cereus was the probable etiological agent (Kramer \& Gilbert, 1989)

\begin{tabular}{|l|l|l|}
\hline Country & Type of food & B. cereus isolated /g or /ml \\
\hline Germany & Meat-balls & Not recorded \\
\hline Sweden outbreaks & Meats and meat products & Not recorded \\
\hline Norway & "Yellow pudding desserts" & $1.3 \times 10^{7}$ \\
\hline Italy & Chicken soup & $6.0 \times 10^{7}$ \\
\hline Norway & Vanilla sauce & $2.5 \times 10^{7}-1.1 \times 10^{8}$ \\
\hline Netherlands & Mashed potatoes, meats, rice & $5 \times 10^{5}-2 \times 10^{8}$ \\
\hline dishes, puddings, soups & Vegetable soup dishes, & $3.6 \times 10^{4}-9.5 \times 10^{8}$ \\
\hline Hungary outbreaks & $\begin{array}{l}\text { Sausage, vegetable } \\
\text { cream pastries, soups }\end{array}$ & $10^{7}$ \\
\hline USA & Meat- loaf & $10^{6}-10^{7}$ \\
\hline UK & Rice dishes & Not recorded \\
\hline
\end{tabular}

The discrepancy between cases of food poisoning and reported cases involving dairy products could be due to the mild and short illness periods experienced by individuals (not outbreaks) who might attribute the sickness to other foods consumed with the cheese. Rangasamy et al (1994) found B. cereus in various Victorian milk and dairy products (Table 5). Ahmed et al (1983) reported the presence of $B$. cereus in $9 \%$ of raw milk, $35 \%$ pasteurised milk, $14 \%$ Cheddar cheese and $48 \%$ of ice cream in the United States of America. Apart from public health problems, Bacillus cereus is associated with sweet curdling of milk and bitty cream (Stone \& Rowlands, 1952). Ingestion of food containing $10^{4}-10^{7}$ cells or spores per gram may cause food poisoning (Granum, 1994). Therefore surveillance of B. cereus in cheese 
preparations will remain significant as there is no process control that can completely avoid its presence. Preservatives like $\mathrm{NaNO}_{3}$ are utilised in some countries, however its use is forbidden in other countries. In some countries such as the United States of America lysozyme has been tried as an inhibitor for B.cereus (Johnson et al, 1990).

Table 5 Occurrence of $B$. cereus in milk and dairy products manufactured in Victoria (Rangasamy et al, 1994)

\begin{tabular}{|c|c|c|c|c|}
\hline \multirow[t]{2}{*}{ Dairy product } & \multirow[t]{2}{*}{ No of samples } & \multicolumn{2}{|c|}{ No of samples with $B$, cereus } & \multirow{2}{*}{$\begin{array}{l}\text { Range of counts } \\
(\mathrm{cfu} / \mathrm{ml} \text { or } \mathrm{g})\end{array}$} \\
\hline & & KG agar & PEMBA agar & \\
\hline Raw milk & 24 & 6 & 3 & $<10$ \\
\hline Pasteurised milk & 12 & 4 & 2 & $<10-28$ \\
\hline Yoghurt & 15 & 3 & 4 & $60-430$ \\
\hline Cheddar cheese & 10 & 4 & 2 & $30-100$ \\
\hline UHT milk & 10 & 0 & 0 & - \\
\hline Milk powder & 10 & 3 & 1 & $30-960$ \\
\hline Ice cream & 10 & 4 & 4 & $30-160$ \\
\hline Total & 91 & 24 & 16 & - \\
\hline
\end{tabular}

\subsubsection{Prevention of growth of $B$. cereus}

The widespread distribution of $B$. cereus, the ability of spores to survive long-term storage in dried products, and the thermal resistance of spores help to explain the wide variety of foods that have been implicated in $B$. cereus food borne illness outbreaks. The fact that the organism naturally exists in numerous foods prevents the establishment of rigorous specifications that would preclude the presence of B. cereus in ingredients (Johnson, 1984; Macrae et al, 1993). Therefore, one should assume that $B$. cereus is always present and should take measures to prevent growth during food handling.

Bryan (1972) has reviewed factors that contribute to food borne illness outbreaks. Inadequate cooling was the most important factor leading to disease outbreaks. Inadequate cooking, preparation of food far in advance, and infected personnel were also important factors. Control 
of $B$. cereus food poisoning should rely on the prevention of spore germination and prevention of multiplication of vegetative cells in prepared food (Macrae et $a l, 1993$ ). Therefore foods should be cooled rapidly to $4^{\circ} \mathrm{C}$ or maintained above $63^{\circ} \mathrm{C}$, and they should be reheated thoroughly to a temperature above $74^{\circ} \mathrm{C}$ before serving (Johnson, 1984; Macrae et al, 1993). These recommendations are applicable to any food product in which growth of $B$. cereus is possible.

In milk many methods have been investigated as means of controlling the growth of B. cereus. However, due to strain variations, no method can be considered ideal (Griffiths, 1992). The most appropriate action still remains good husbandry practices to minimise entrance of this ubiquitous organism into the milk supply and to keep milk as cold as possible during milk production and storage.

\subsubsection{Legislation}

According to the South African regulation relating to Herbs and Spices (R1468) of the Foodstuffs, Cosmetics and Disinfectants Act (Act 54 of 1972) any foodstuff containing $B$. cereus in $20 \mathrm{~g}$ of sample is deemed harmful or injurious to human health. Notermans, Dufrenne, Teuns, Beumer, Giffel \& Weem (1997) noted that for most European countries numbers of $10^{4}-10^{5}$ per $\mathrm{ml}$ or gram of a product at the expiry date are considered to be the critical limits of acceptance of a particular food. For epidemiological surveys any counts greater than $10^{5}$ per gram would indicate $B$, cereus as the etiological agent of outbreaks of food poisoning. For cheese products mere presence of $B$. cereus is sufficient cause of concern and levels above $10^{5}$ per gram indicate bad manufacturing practices (Johnson et al, 1990)

\subsection{STARTER CULTURES}

The preservation of food by fermentation is one of the oldest methods of food preservation known to mankind (Scott, 1986). The lactic acid fermentation is widely used during the manufacture of fermented dairy products. Such a fermentation process is the result of the presence of microorganisms known as starter cultures. The most important group of starter bacteria is the lactic acid bacteria which include the genera Streptococcus, Leuconostoc and Lactobacillus (Tamime, 1981). In the dairy industry, interest is mainly focused on the genera Streptococcus, Lactobacillus and Leuconostoc. The genus Streptococcus is widely 
used in the cheese industry and examples from this genus are S. lactis (Lactococcus lactis), S. lactis subsp. diacetylactis (Lactococcus lactis subsp. lactis biovar diacetylactis), S. cremoris (Lactococcus lactis subsp. cremoris) and S. thermophilus. These organisms are homofermentative, producing only lactic acid from glucose, and with the exception of $S$. thermophilus, are classified as mesophilic bacteria (Tamime, 1981). Of the genus Leuconostoc, only $L$. cremoris and $L$. dextranicum are associated with dairy starter cultures. They are heterofermentative organisms capable of producing lactic acid, diacetyl, carbon dioxide and aroma compounds such as ethanol and acetic acid from glucose (Tamime, 1981). The genus Lactobacillus is divided into three main groups; Thermobacterium, Streptobacterium and Betabacterium. The former two sub-groups are homofermentative and the species used in the dairy industry are L. bulgaricus, L. lactis, L. acidophilus, L. helveticus, L. casei and L. plantarum (Tamime, 1981). However, various strains of microorganisms can be used as starter cultures in the dairy industry.

\subsubsection{Classification of dairy starter cultures}

Starter cultures may consist of either single strains, multiple strains of the same species, or a mixture of different species or genera; thus giving the dairy industry the opportunity to manufacture different types of fermented dairy products. Table 6 illustrates the application of those microorganisms which are required for the production of cheese. 
Table 6 Lactic acid bacteria employed as starter cultures for cheese-making (Tamime, 1981)

\begin{tabular}{|c|c|}
\hline Bacteria & Examples of usage \\
\hline \multicolumn{2}{|l|}{ Mesophilic starters ${ }^{\mathrm{a}}$} \\
\hline L. lactis subsp. cremoris and L. lactis & Hard-pressed cheese, e.g. Cheddar, Gouda; \\
\hline subsp. lactis & Mould-ripened, e.g. Stilton \\
\hline $\begin{array}{l}\text { L. lactis subsp. lactis biovar diacetylactis } \\
\text { and Leuconostoc spp. }\end{array}$ & $\begin{array}{l}\text { Soft, ripened, e.g. Camembert, Feta, many } \\
\text { other types }\end{array}$ \\
\hline L. lactis subsp. cremoris & Soft, unripened, e.g. Coulommier, \\
\hline $\begin{array}{l}\text { L. lactis subsp. Lactis biovar diacetylactis } \\
\text { Leuconostoc cremoris }\end{array}$ & Cottage cheese, Quarg, Cream cheese \\
\hline \multicolumn{2}{|l|}{ Thermophilic starters ${ }^{6}$} \\
\hline$S$. thermophilus with $L$. helveticus, & Swiss-type, e.g. Emmenthal; \\
\hline L. lactis or L. bulgaricus & Italian, very hard, e.g. Parmesan; \\
\hline & Semi-soft, smear types e.g. Limburger \\
\hline \multicolumn{2}{|l|}{ Mixed starters } \\
\hline L. lactis, S thermophilus or S. faecalis & Italian pasta filata type, e.g. Mozzarella, \\
\hline and $L$. bulgaricus & Provolone \\
\hline
\end{tabular}

a Optimum growth temperature $20-30^{\circ} \mathrm{C}$

is Optimum growth temperature $37-45^{\circ} \mathrm{C}$ 
Mesophilic lactic starter cultures (optimum temperature $20-30^{\circ} \mathrm{C}$ ) are widely used. In the cheese industry they are divided into single, multiple or mixed strains. Single strain starters consist only of one type of organism, but in practise they are rarely used. Mixed strain starter cultures consist of known numbers of single strains, so that the starter can be used for an extended period of time during the cheese-making season (Kosikowski, 1978; Tamime, 1981). A mixed strain starter is a combination of L. lactis, L, lactis subsp. cremoris and the gas and aroma producing mesophilic lactic acid bacteria, L. lactis subsp. lactis biovar diacetylactis, Leuconostoc cremoris and/or L. dextranicum (Kosikowski, 1978; Tamime, 1981). The lactic acid bacteria ferment lactose to form mainly lactic acid. The mixed mesophilic cultures are also called the flavour producers because of their ability to produce diacetyl, the flavour compound from citrate fermentation (Cogan, 1995). Depending on their citrate-utilising component $\left(\mathrm{Cit}^{+}\right)$mixed mesophilic cultures are assigned to the following types: $\mathrm{D}$ type with $\mathrm{Cit}^{+}$Lactococcus species as the only flavour producer, $\mathrm{L}$ type with $\mathrm{Cit}^{+}$Leuconostoc as the only flavour producer or DL types with both flavour producers present. $\mathrm{O}$ or $\mathrm{N}$ type cultures are those lacking flavour producers (Cogan, Peitersen \& Sellars, 1991). The classification of dairy starter cultures is summarised in (Figure 3). Successful production of cheese relies completely on choosing the right organism (Tamime, 1981). 

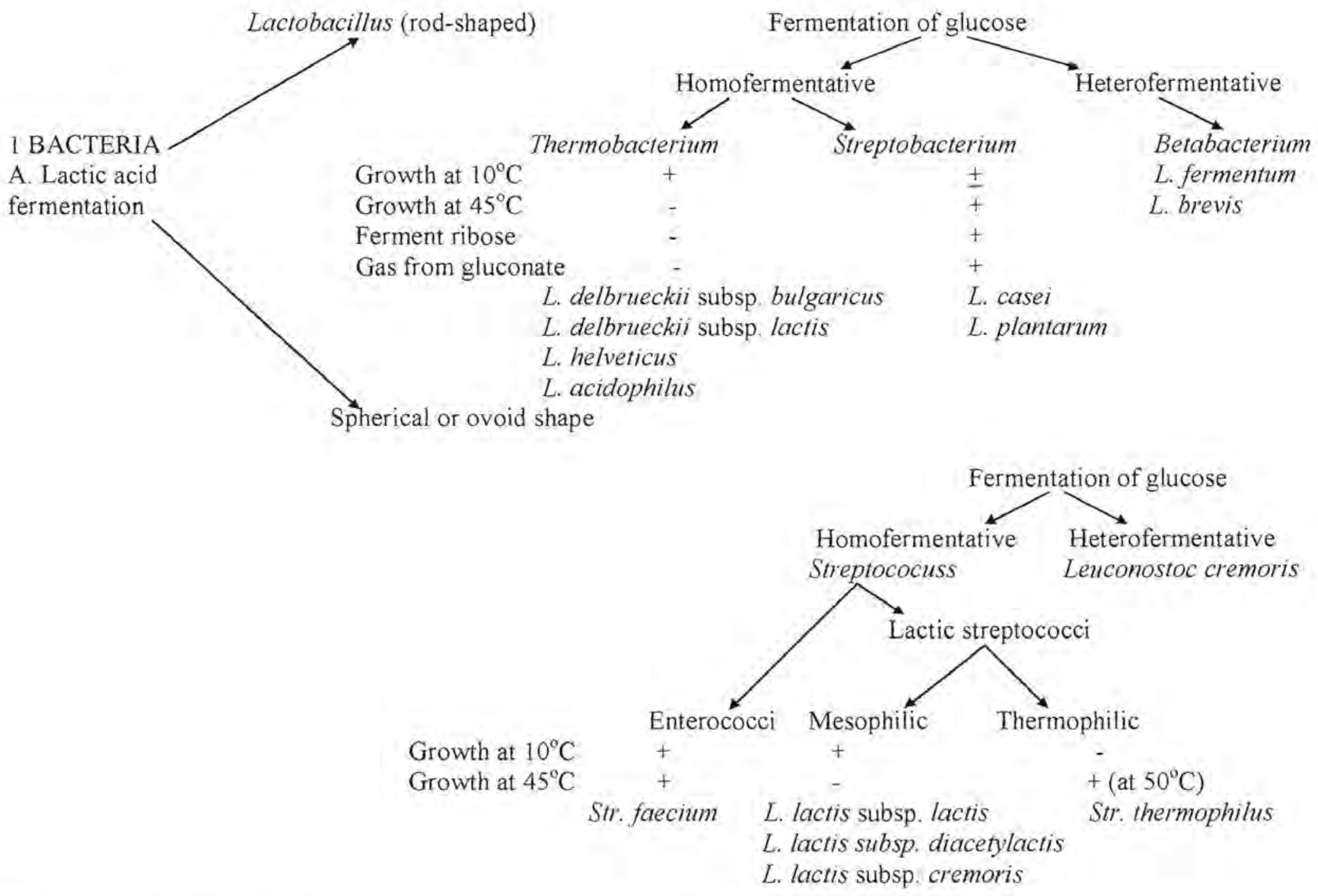

Figure 3 Classification and differentiation of dairy starter cultures (Tamime, 1981) 


\subsubsection{Fermentation of lactose by lactic acid bacteria (LAB)}

Fermentation: of lactose to lactate by lactic acid bacteria is the major metabolic reaction occurring in cheese manufacture. Addition of starter culture to the milk results in an initial population of $\sim 1 \times 10^{7}$ cells per $\mathrm{ml}$ and they increase to $\sim 1 \times 10^{9}$ cells per gram of cheese (Cogan et al, 1991). Such large populations ensure rapid metabolism of residual lactose and result in lactate concentration of $100-170 \mathrm{mmol}$ per $\mathrm{kg}$ of cheese. The rate of lactose fermentation depends, however, on the manner of salting the cheese. In brine-salted cheese (e.g. Dutch and Swiss types), diffusion of salt into the cheese is relatively slow and lactose metabolism occurs over an extended period. This contrasts with dry-salted cheeses (e.g. Cheddar) in which the salt is mixed intimately with the curd and, especially at high concentrations, retards metabolism of residual lactose by the starter culture (Cogan, 1995).

The lactic acid bacteria share the property of producing lactic acid from hexoses. They are divided into two groups based on end products of glucose metabolism. Those that produce lactic acid as the major or sole product of glucose fermentation are the homofermentative types (Figure 4 - 1A). Those lactics that produce equal molar amounts of lactate, carbon dioxide and ethanol from hexoses are designated heterofermentatives (Figure 4 - 1B). All members of the genera Pediococcus, Sreptococcus, Lactococcus, Vagococcus and some of the lactobacilli are homofermentative, while Leuconostoc spp., as well as some lactobacilli are heterofermentative. 


\section{GLUCOSE}

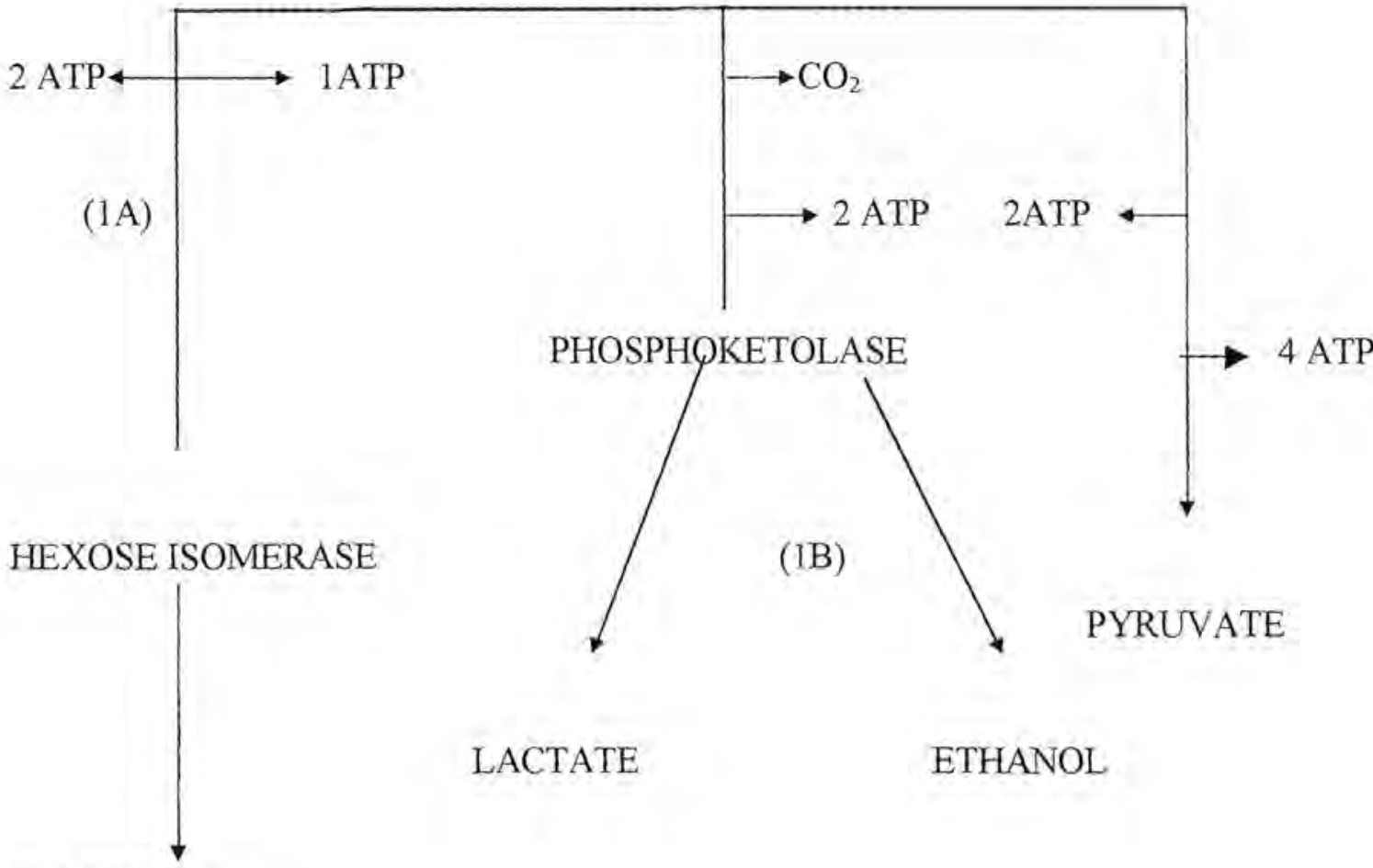

2 LACTATE

Figure 4. Generalised pathways for the production of some fermentation products from glucose by : (1A) Homofermentative lactics; (1B): heterofermentative lactics (Jay, 1992)

\subsubsection{Factors affecting growth of starter cultures}

For many years the problem of bacteriophage has been the most serious one confronting the cheesemaker because of the economic losses it entails (Cogan et al, 1991). Phage multiplication decreases the ability of the culture to produce acid, which in turn decreases the expulsion of whey, i.e synerisis of the curd and in the extreme cases complete inhibition of acid production or "dead vats" occur (Cogan et al, 1991). Extreme care must be exercised during the transfer of cultures to maintain them free from bacteriophage contamination. Removing the calcium ions from the culture media, or binding them by addition of phosphates, oxalates or citrates is an effective way to control this contamination (Rosenthal, 1991). A number of other factors can be responsible for the inhibition of starter activity in milk (Table 7). 
Table 7 Factors responsible for inhibition of starter cultures (Rosenthal, 1991)

Natural inhibitors in milk

Mastitis milk

Free fatty acids in rancid milk

Antibiotic residues in milk

Bactericide residues

Bacteriophage contamination
The content varies with the individual animal and can be destroyed by heat

Phagocytosis of the starter organism by the leucocytes

Correct handling of raw milk. Rejection of rancid milk

Rejection of antibiotic milk

Negligent operation may leave sanitizer residues in milk. Quaternary ammonium compounds have the greatest inhibiting effect, even at concentration of $3 \mathrm{mg} / \mathrm{l}$, chlorine compounds are inhibiting above $5 \mathrm{mg} / \mathrm{l}$, while iodophors show no effect up to $50 \mathrm{mg} / \mathrm{l}$.

Prevention of phage contamination 


\subsubsection{Effect of lactic acid bacteria on survival and growth of $B$. cereus}

Lactic acid bacteria are useful for the enrichment of flavour, palatability, therapeutic value and their ability to suppress many undesirable microorganisms and pathogens (Roberts \& Skinner, 1983). From historical times production of lactic and acetic acid and the consequent reduction in $\mathrm{pH}$ has been utilised to preserve or prolong the shelf life of many foods including cheese. Research has also unearthed some other inhibitory substances produced such as hydrogen peroxide, alcohol, acetaldehyde, diacetyl and bacteriocins like nisin. However, B. cereus produces nisinase which can counter the effect of nisin if sufficient quantities are produced (Goepfert et al, 1992). Beuchat, Clavero \& Jaquette (1997) demonstrated that $1 \mu \mathrm{g}$ nisin per $\mathrm{ml}$ of beef gravy was lethal to $B$. cereus, the effect being greater on vegetative cells than spores. $B$. cereus is a poor competitor and it grows well only when other microorganisms have been reduced by heat or pasteurisation. The antagonism may be derived from substrate depletion and the reduction of oxidation-reduction potential (Eh). In the absence of competing flora $B$. cereus can grow to numbers that can cause food poisoning (Goepfert et al, 1992).

Lodi \& Malaspina (1992) studied the interaction of B. cereus and the lactic acid bacteria in fresh cheeses (Figure 5). Lactic acid bacteria affected B. cereus differently in three types of fresh cheeses which were inoculated with varying quantities of vegetative cells. In fresh cheese type A, B. cereus decreased rapidly and disappeared within a week; on the contrary when inoculated into fresh cheeses type B and type C, B. cereus decreased only slightly. Strains of lactic acid bacteria which yield substances or an environment inhibiting $B$. cereus when used to produce dairy products continue to be the subject of research. 


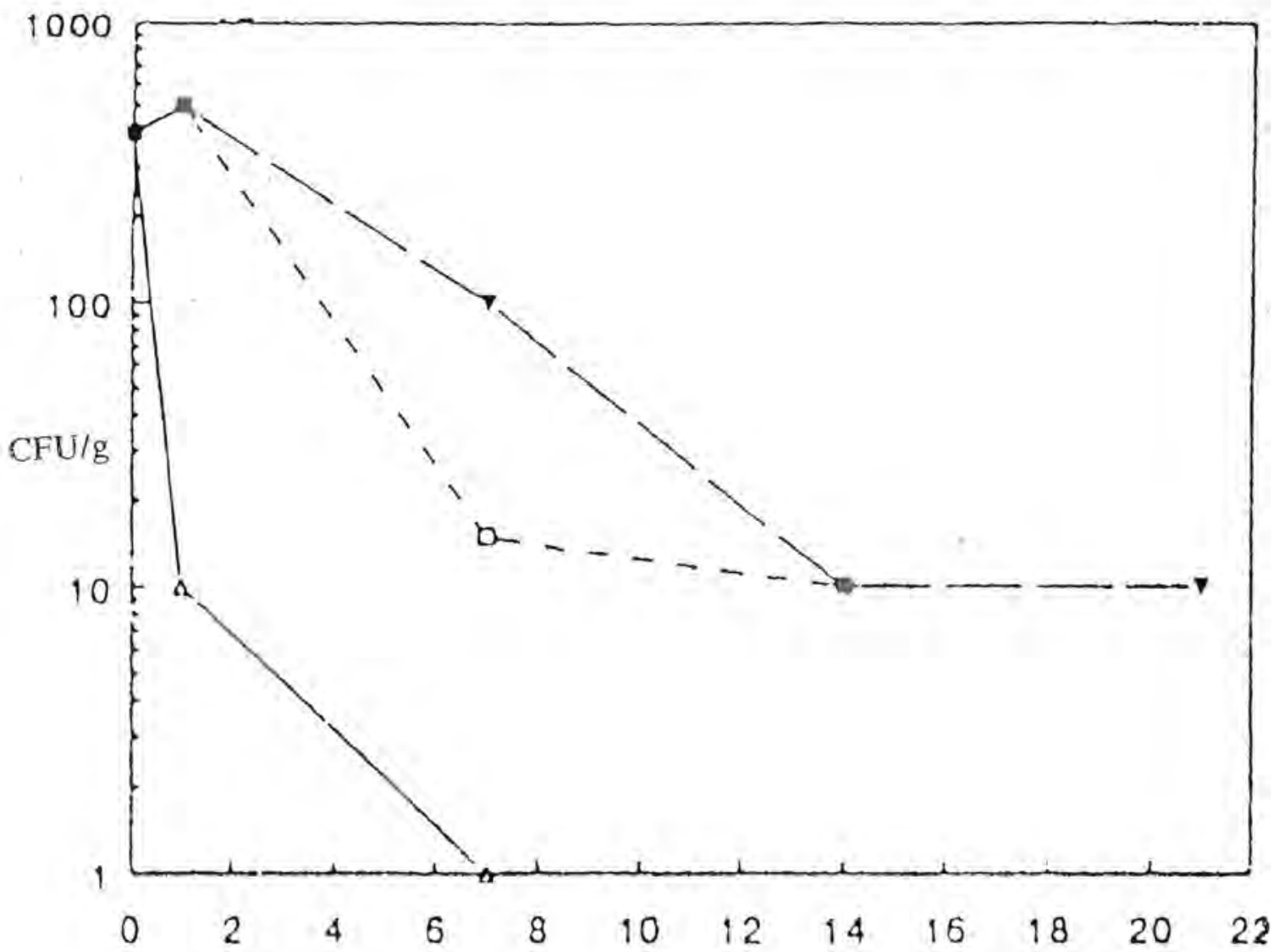

DAYS

Figure 5 Growth of Bacillus cerens artificially inoculated in three types of cheeses ( $\triangle-$ type $A,-7-$ type B, $\mathbb{\nabla}$-type C) (Lodi \& Malaspina, 1992)

\subsubsection{Antimicrobial substances produced by lactic acid bacteria}

Lactic acid bacteria are capable of producing substances other than organc acids (lactate and acetate) that are antagonistic toward other microorganisms (Daeschel, 1989). These substances are produced in much smaller amounts and include hydrogen peroxide, diacetyl, bacteriocins and secondary reaction products such as hypothiocyanate generated by the action of lacto-peroxidase on hydrogen peroxide and thiocynate 


\subsubsection{Hydrogen peroxide}

The lactobacilli have the ability to generate hydrogen peroxide in the presence of oxygen through the action of flavoprotein oxidases or NADH oxidases (Figure 6).

Pyruvate $+\mathrm{O}_{2}+\mathrm{PO}^{3 \cdot} \longrightarrow \longrightarrow$ Acetyl phosphate $+\mathrm{CO}_{2}+\mathrm{H}_{2} \mathrm{O}_{2}$

pyruvate oxidase

Lactate $+\mathrm{O}_{2}$ pyruvate $+\mathrm{H}_{2} \mathrm{O}_{2}$

L- lactate oxidase

Lactate $+\mathrm{O}_{2}$

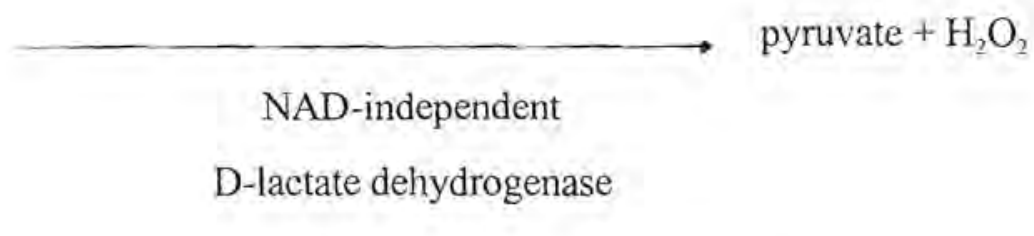

$\mathrm{NADH}+\mathrm{H}^{*}+\mathrm{O}_{2}$

$\mathrm{NAD}+\mathrm{H}_{2} \mathrm{O}_{2}$

NADH oxidase

Figure 6 Mechanisms of hydrogen peroxide generation by lactic acid bacteria (Daeschel, 1989).

According to Kandler \& Weiss (1986), accumulation of hydrogen peroxide in growth media can occur because lactobacilli do not possess the catalase enzyme. In raw milk hydrogen peroxide generated by lactic acid bacteria can react with endogenous thiocynate (catalysed by lactoperoxidase) to form a "Lactoperoxidase antibacterial system" which can be useful in extending the shelf life of unrefrigerated raw milk (Bjork, 1993). 


\subsubsection{Diacetyl}

Diacetyl is best known for the buttery aroma that it imparts to cultured dairy products. This substance is produced by the genera Lactococcus, Leuconostoc, Lactobacillus and Pediococcus (Daeschel, 1989). Apart from being a flavour compound, Jay (1982) showed that $300 \mu \mathrm{g} / \mathrm{ml}$ diacetyl was inhibitory to non-lactic acid bacteria that were Gram-positive. Lactic acid bacteria were not inhibited at a concentration of $350 \mu \mathrm{g} / \mathrm{ml}$ (Jay, 1982). Although diacetyl is generally recognised as safe (GRAS), its utility as food preservative is limited because of the relatively large amounts needed to provide preservation.

\subsubsection{Bacteriocins}

Bacteriocins are a type of antimicrobial substances, protein in nature, which produce inter- and intra-species effects (Daeschel, 1989). A number of bacteriocins have been produced by the genera Lactobacillus, Pediococcus and Lactococcus. Bacteriocins and bacteriocin-like substances produced by strains of lactobacilli and lactococci are mainly active against Grampositive organisms (Spahr \& Url, 1994). Some of these substances are Bavaricin A produced by Lactobacillus bavaricus M140 and Plantaricin UGI produced by Lactobacillus plantarum UGI (Enan, El-Essawy, Uyttendale \& Debevere, 1996). Nisin is produced by some strains of Lactococcus lactis. Its antimicrobial effect is directed against the bacterial cytoplasmic membrane. It is particularly effective against spore forming organisms e.g Bacillus and Clostridium because of their vulnerable cytoplasmic membrane (Spahr \& Url, 1994).

The minimum inhibitory concentration of nisin against these bacteria varies from 0,25 to 500 $\mathrm{IU} / \mathrm{g}$ when measured on an agar diffusion test. The most important application in dairy products is in processed cheese to inhibit growth of anaerobic sporeformers. Concentrations of 100-200 IU per gram of cheese are used for this purpose (Spahr \& Url, 1994). 


\subsection{GOUDA CHEESE MANUFACTURING}

\subsubsection{Overview of Gouda cheese manufacture}

Gouda, like other cheese varieties, is made from cow's milk, using rennet and starter cultures. The variety of cheese produced is determined by the type of milk used, the type of starter (lactic acid bacteria) responsible for the development of acid, characteristic features and flavour. The starter culture used for Gouda cheese is a mixture of streptococci, leuconostoc and lactobacilli (Kosikowski, 1978; Tamime, 1981). Typical Gouda cheese has a distinct yellow colour, waxy body, with a mild nutty flavour and a few holes evenly distributed throughout the cheese (Kosikowski, 1978). 


\subsubsection{Basic steps in the manufacture of Gouda cheese}

The basic procedure for cheese-making is shown in Figure 7.

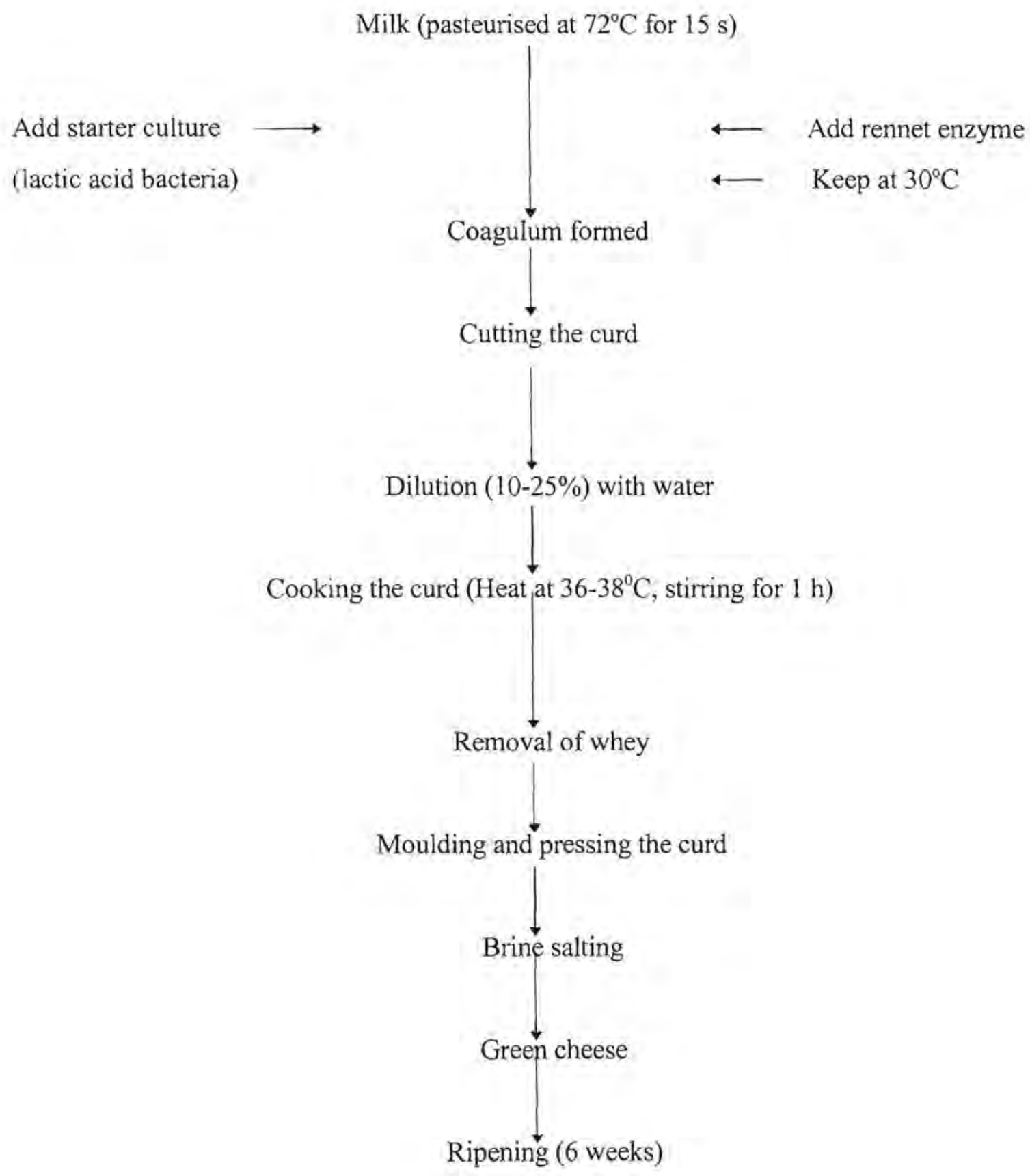

Figure 7 Flow diagram for cheese manufacture 


\subsubsection{Coagulation (Curd formation)}

Pasteurised milk is inoculated with a starter culture and rennet added to form a curd. Renneting of milk takes place in three phases:

a) An enzymic, destabilising phase where the protective colloidal nature of $k$-casein is destroyed and para-k-casein is formed within the casein micelles (Tamime, 1981). This phase can occur at refrigeration temperatures.

b) A non-enzymic, coagulation phase which can proceed only at higher temperatures.

c) A mainly proteolytic phase which takes place around $\mathrm{pH} 5.2-5.8$ and includes the breakdown of milk proteins to peptides. The last phase is essential for cheeseripening. Peptides formed are utilised and further degraded by the starter cultures (Kosikowski, 1978; Tamime, 1981).

\subsubsection{Cooking (scalding) and whey removal}

The curd is cut into small particles. These are lightly scalded by removing about $10-25 \%$ of whey and replacing it with an equal amount of water at $50-60^{\circ} \mathrm{C}$. Addition of water raises the vat temperature and also dilutes the lactose content of the curd. The growth of lactic acid bacteria is thus decreased resulting in Gouda cheese with higher $\mathrm{pH}$. High cooking temperatures help in lowering the moisture content and proteins are changed resulting in a more elastic, spongy type of curd.

The starter bacteria are trapped in the coagulum at rennetting and most are retained in the curd particles after cutting. The trapped lactic acid bacteria continue to ferment lactose within the curd particles after cutting. The acid produced will also accelerate expulsion of moisture. The extent of acid production by lactic acid bacteria has a marked effect on the chemical and physical composition of the curd and control of acid development is important (Kanawjia, Toyoda, Kitamura \& Ahiko, 1991; Johnson, Steele, Broadbent \& Weimer, 1998). 


\subsubsection{Salting}

After the whey has been drained off, curds are filled into moulds and pressed lightly. The cheese is then salted in a brine bath. After brining the cheese is dried to form a coat and ripened for about six weeks. Lactic acid bacteria vary in their tolerance to salt. Strains of $L$. lactis subsp. cremoris are inhibited by $2 \%$ salt but L. lactis subsp. lactis can withstand up to $4 \%$ salt. Suppression by salt of the growth of undesirable proteolytic, lipolytic and other spoilage bacteria, such as butyric acid bacteria is of importance in Gouda cheese where low levels of lactic acid are produced during curdmaking (Tamime, 1981; Scott, 1986).

Brining of the cheese serves not only as a means to get salt into the cheese, but also to cool the cheese and delay gas formation (Johnson et al, 1998). In most cheese varieties, salt concentration attain levels of $1.6-2.5 \%$ in the total cheese which would not affect most of the pathogenic bacteria in cheese, but it is realised that salt is dissolved in the aqueous phase of the cheese only, the actual site of bacterial growth. In the aqueous phase salt reach levels of 2.2 $6.5 \%$ and these will at least slow down the growth rate of most bacteria and may even have a lethal effect on the more sensitive ones (Spahr \& Url, 1994).

\subsubsection{Ripening}

The cheese taken out of the press has a mild acid taste and aroma but does not possess the characteristic cheese flavour (Kanawjia et al, 1991). During ripening, characteristic changes take place regarding the body, texture and flavour of the cheese (Scott, 1986). The chemical changes responsible for cheese-ripening are:

a) Fermentation of lactose: Lactose is fermented to lactic acid, small amounts of acetic acid and propionic acid, $\mathrm{CO}_{2}$ and diacetyl.

b) Proteolysis and lipolysis: These changes are brought about by enzymes from lactic itself and microorganisms growing within or on the surface of the cheese. 
The starter bacteria die out during ripening, as do most organisms present in the curd. Survival of B.cereus is also compromised by the production of lactic acid within the curd, the salt, the low $\mathrm{a}_{\mathrm{w}}$ and Eh. Only the lactobacilli, which may be present in fresh curd in small numbers, multiply and these may reach levels of $10^{6}-10^{8} \mathrm{~g}^{-1}$ in cheese in $3-6$ weeks (Chapman \& Sharpe 1981; Scott, 1986). Gouda cheese with a relatively low moisture content, can be matured for a longer time and this results in more protein breakdown and rather more flavour in the cheese (Chapman \& Sharpe, 1981). High levels of contaminants in milk may result in spoilage even at satisfactory concentration of moisture, salt and acidity.

\subsection{Nutritional aspects of cheese}

Milk is often described as nature's most nearly perfect food. Cheese, however, because of the selective concentration of components, differ from milk in this respect. The dairy industry turns milk, a short life commodity, into cheese with a shelf life of from $4-5 \mathrm{~d}$ up to $5-10 \mathrm{~m}$ (Scott, 1981).

In addition, microbial fermentation adds a new dimension of nutrition to cheese. Lactic acid, lactates, free fatty acids, amino acids, carbonyls and a variety of smaller molecular compounds are formed, and these influence the nutritive property of the fermented foods (Kosikowski, 1978). Furthermore, natural antibiotics which do not normally appear in dairy foods of unfermented nature are produced by the added bacterial cultures (Kosikowski, 1978) 
Table 8 Nutrients of cheese per $100 \mathrm{~g}$ of cheese (adapted from Scott, 1986)

\begin{tabular}{|c|c|c|c|c|c|c|c|c|c|c|}
\hline Food & $\begin{array}{l}\text { Protein } \\
\mathrm{N} \times 6.26 \\
\text { (g) }\end{array}$ & $\begin{array}{l}\text { Fat } \\
\text { (g) }\end{array}$ & $\begin{array}{c}\text { Calcium } \\
\text { (mg) }\end{array}$ & $\begin{array}{l}\text { Iron } \\
\text { (mg) }\end{array}$ & $\begin{array}{l}\text { Thiamine } \\
\text { (mg) }\end{array}$ & $\begin{array}{l}\text { Retinol } \\
(\text { vitamin A) } \\
(\mu g)\end{array}$ & $\begin{array}{c}\text { Riboflavin } \\
\text { (mg) }\end{array}$ & $\begin{array}{l}\text { Ascorbic acid } \\
\text { (Vitamin C) }\end{array}$ & $\begin{array}{l}\text { Nicotinic } \\
\text { acid }(\mathrm{mg})\end{array}$ & $\begin{array}{r}\text { Energy } \\
\text { (kcal) }\end{array}$ \\
\hline Cheddar & 26.0 & 33.5 & 800 & 0.5 & 0.04 & 310 & 0.5 & 0 & 0.5 & 406 \\
\hline Soft cheese & 22.8 & 25.5 & 150 & 0.4 & 0.06 & 155 & 0.4 & 0 & 0.4 & 285 \\
\hline Cottage cheese & 13.6 & 4.0 & 60 & 0.1 & 0.09 & 32 & 0.3 & 0 & 0.3 & 96 \\
\hline
\end{tabular}




\section{CHAPTER 3}

\section{MATERIALS AND METHODS}

\subsection{Manufacturing of Gouda cheese}

\subsubsection{The milk}

Milk was obtained from the University of Pretoria's experimental farm. A vegetable colouring (annatto) and rennet (Rennilase Type T, manufactured by Novo Industries, Denmark) were obtained from the University of Pretoria's existing stock. The materials were kept in a cold room at $4^{\circ} \mathrm{C}$.

\subsubsection{The starter culture}

\subsubsection{Mother cultures}

The starter culture used, was a commercial culture $\mathrm{CHN}_{22}$ (a mixed culture of Lactococcus lactis and L. lactis subsp, cremoris). The stock cultures were supplied in feeze-dried form by CHR Hansen's Laboratories (Denmark) and distributed locally by Darleon (Johannesburg). Reconstituted skim milk was dispensed in $10 \mathrm{ml}$ portions in McCartney bottles and the caps were screwed on. The bottles of reconstituted milk were then sterilised at $121^{\circ} \mathrm{C}$ for $15 \mathrm{~min}$ and cooled to room temperature. The freeze-dried culture was activated by aseptically transferring a small amount into $10 \mathrm{ml}$ sterilised milk. This was then incubated at $22^{\circ} \mathrm{C}$. After incubation the starter culture (mother culture) was cooled to less than $5^{\circ} \mathrm{C}$ and kept in a refrigerator. The mother culture was maintained by daily subculturing in sterilised milk, using a $1 \%$ inoculum $(0.1 \mathrm{ml}$ in $10 \mathrm{ml}$ sterile milk), incubation at $22^{\circ} \mathrm{C}$ for $12-16 \mathrm{~h}$ and storing the culture at $<5^{\circ} \mathrm{C}$ in a refrigerator.

\subsubsection{Bulk cultures}

The bulk starter culture was prepared by inoculating $10 \mathrm{ml}$ of the mother culture into 1000 $\mathrm{ml}$ of sterilised reconstituted milk ( $1 \%$ inoculation rate), incubating the inoculated milk at $22^{\circ} \mathrm{C}$ for $12-16 \mathrm{~h}$ and then cooling the bulk culture to $<5^{\circ} \mathrm{C}$ and keeping it at this temperature until it was used. 
3.1.3 Manufacturing of the cheese

Gouda type cheese was manufactured in the pilot plant of the Department of Food Science (University of Pretoria) using the method described by Kosikowski (1978). Milk was pasteurized in a batch pasteurizer at $63^{\circ} \mathrm{C}$ for $30 \mathrm{~min}$ and cooled down to $30^{\circ} \mathrm{C}$. The milk was then inoculated with $0.75 \%$ of the starter culture and then rennet added at the rate of 3 $\mathrm{ml}$ per $100 \mathrm{l}$ of milk. After approximately $30 \mathrm{~min}$ at $30^{\circ} \mathrm{C}$, the coagulated milk was cut using knives with blades $6 \mathrm{~mm}$ apart. Ten minutes later part of the whey was removed and replaced with warm water $\left(32-42^{\circ} \mathrm{C}\right)$ to $10 \%$ of the milk volume. After another ten minutes, the curd was slowly heated from $30^{\circ} \mathrm{C}$ to $36^{\circ} \mathrm{C}$ over a period of 30 to $45 \mathrm{~min}$. When the curd had attained a temperature of $36^{\circ} \mathrm{C}$, whey was drained to $50 \%$ of the original volume of milk. The curd was held at $36^{\circ} \mathrm{C}$ for $1-1 \frac{1}{2} \mathrm{~h}$. The whey was then drained and the curd was put into warm moulds and pressed lightly for about $3-4 \mathrm{~h}$. After pressing, the cheeses were redressed and left in the mould overnight without applying pressure. The green cheese $(\sim 10 \mathrm{~kg}$ each $)$ was cut into six pieces $(\sim 1,6 \mathrm{~kg}$ each) and placed in a brine solution $\left(20 \%{ }^{\mathrm{w}}\right.$, salt, $\mathrm{pH} 5$ at $\left.12-15^{\circ} \mathrm{C}\right)$ for $24 \mathrm{~h}$. The green cheese was removed from the brine and allowed to dry for two days in the cheese curing room. After drying, the green cheese was vacuum packed and ripened in a curing room at 12 $15^{\circ} \mathrm{C}$ ( $\mathrm{RH} 80-85 \%$ ) for 6 weeks. Examples of the cheese manufacturing records are given in Appendix 1.

\subsection{Preparation of B.cereus spore suspensions}

\subsubsection{Growth and sporulation of the cultures}

B. cereus spores were produced on KG agar slants (Refai, 1979). Growth from a previous grown culture was suspended in $2-5 \mathrm{ml}$ sterile distilled water by gently removing the growth from the agar medium with the aid of a sterilised (flamed) glass rod. This suspension was used as inoculum. The prepared agar slants $(100 \mathrm{ml})$ were inoculated with a $0,5 \mathrm{ml}$ of inoculum, spreading the inoculum as evenly as possible over the slant. The inoculated slants were incubated for $3-7 \mathrm{~d}$ at $30^{\circ} \mathrm{C}$. After incubation the cultures were left on the bench at room temperature until $\sim 80 \%$ sporulation had occurred. The rate of 
sporulation was determined by preparing a smear of the culture on a glass slide, staining with crystal violet stain and examining under the microscope (Carl Zeiss Co., West Germany). Spores appeared as unstained oval structures.

\subsubsection{Harvesting of the spores}

Spores were washed off the sporulation medium with sterile distilled water using a sterile (flamed) glass rod to dislodge growth from the agar slants. Spores were gently removed from the medium and pooled into a sterile Ehrlenmeyer flask. The pooled suspension was then transferred to a sterile centrifuge tube which was covered with an aluminium foil cap. The tubes were balanced and centrifuged for $10 \mathrm{~min}$ at $3000 \mathrm{r} / \mathrm{min}$. The supernatant was poured off and the spores were washed by adding fresh sterile distilled water. The spores were then resuspended with the aid of a sterile glass rod and centrifuged again. The spores were washed and centrifuged five times. After washing the spores, they were resuspended in sterile distilled water and sterile glass beads were added to separate clumps by hand shaking. The concentration of the spores was then adjusted with sterile distilled water to $\sim 10^{7}$ per $\mathrm{ml}$ (40-80\% Transmission and wavelength of $420 \mathrm{~nm}$ ) using a spectrophotometer (Spectronic 20D, Milton Roy, USA.). The concentration was checked by the Breed Microscopic count method (Harrigan \& McCance, 1976). The spore suspension was then stored at $4-7^{\circ} \mathrm{C}$ in sterile McCartney bottles.

\subsection{Survival and growth of $\boldsymbol{B}$. cereus during Gouda cheese manufacturing}

\subsubsection{Experimental design}

In order to determine the survival and growth of $B$. cereus during Gouda cheese manufacturing, two batches of cheese were prepared.

Batch 1: Experimental cheese with B. cereus spores added

A batch of $100 l$ of whole fresh milk was inoculated with $10 \mathrm{ml}$ of a spore suspension (approximately $10^{7}$ spores of $B$. cereus per $\mathrm{ml}$ ) to give a spore concentration of $10^{2}-10^{3}$ per $\mathrm{ml}$ in the milk. The milk was thoroughly mixed and pasteurised at $63^{\circ} \mathrm{C}$ for $30 \mathrm{~min}$. After pastcurisation the milk was used to manufacture Gouda cheese. 
Batch 2: Control cheese without B.cereus spores added

A second batch of $100 \mathrm{l}$ of whole fresh milk, to which no $B$. cereus spores were added, was pasteurized at $63^{\circ} \mathrm{C}$ for $30 \mathrm{~min}$. After pasteurization the milk was used to manufacture Gouda type cheese.

\subsubsection{Sampling}

Samples were taken at different stages during the Gouda cheese manufacturing and analysed for the parameters as shown in Table 9.

Table 9 Sampling plan during Gouda cheese manufacturing showing process steps and stages at which samples were drawn for microbiological and chemical analyses

\begin{tabular}{|c|c|c|c|c|c|c|}
\hline $\begin{array}{l}\text { Time in weeks } \\
\text { (wk) }\end{array}$ & Process Step & $\begin{array}{l}B . \\
\text { cereus }\end{array}$ & LA & MRS & $\mathrm{pH}$ & TA \\
\hline 0 & Before rennetting & + & ns & ns & + & + \\
\hline 0.004 & Curd at cutting & + & + & + & + & + \\
\hline 0.005 & At $1 / 2$ whey removal & + & + & + & + & + \\
\hline 0.013 & At final whey removal & + & + & + & + & + \\
\hline 0.023 & At hooping (moulding) & + & + & + & + & ns \\
\hline 0.095 & After pressing & + & + & + & + & ns \\
\hline 0.238 & After brining & + & + & + & + & ns \\
\hline 1 & After 1 week & + & + & + & + & ns \\
\hline 2 & After 2 week & + & + & + & + & ns \\
\hline 4 & After 4 weeks & + & + & + & + & ns \\
\hline 6 & After 6 weeks & + & + & + & + & ns \\
\hline
\end{tabular}

$\begin{array}{ll}+ & \text { sample taken } \\ \text { ns } & \text { sample not taken }\end{array}$

LA Lactic agar

MRS Man-Rogosa-Sharpe agar

TA Titratable acidity 


\subsection{Microbiological analyses}

\subsubsection{Preparation of dilutions}

Tenfold serial dilutions of the samples were made by aseptically transferring $25 \mathrm{~g}$ of sample into $225 \mathrm{ml}$ of sterile saline peptone water to give a $10^{-1}$ dilution (IDF, 1992). Samples were then mixed for $20 \mathrm{~s}$ using a Stomacher 400 laboratory blender (Seward Laboratory UAC, Britain). Further tenfold dilutions of up to $10^{8}$ were made by transferring $1 \mathrm{ml}$ of successive serial dilutions into universal bottles containing $9 \mathrm{ml}$ of sterile saline peptone water.

\subsubsection{Plate counts by the spread-plate technique}

Plates for the spread-plate technique were prepared by pouring 12 to $15 \mathrm{ml}$ of the relevant sterile culture media into sterile petri-dishes. The plates were dried at $35^{\circ} \mathrm{C}$ in an incubator. The dried plates were then inoculated with $0.1 \mathrm{ml}$ of the homogenate or dilutions thereof and appropriately labeled. Each inoculum was spread over the surface of the dried plates using a sterile bent glass rod. After incubation the colonies were counted using a Scientific Colony Counter (Stuart Scientific Co., UK) and the results were expressed as $\mathrm{cfu} / \mathrm{g}$ or $\mathrm{cfu} / \mathrm{ml}$ depending on whether the sample was a solid or liquid.

\subsubsection{B. cereus counts}

B. cereus selective medium (Oxoid CM617) was used for the enumeration of $B$. cereus.

The media were prepared according to the manufacturer's instructions and poured into sterile petri-dishes for spread-plate technique (3.4.2). The inoculated plates were incubated at $30^{\circ} \mathrm{C}$ for $24 \mathrm{~h}$, the number of colonies were counted and expressed as $\mathrm{cfu} / \mathrm{g}$ or $\mathrm{cfu} / \mathrm{ml}$ of sample. The plates were also examined for typical $B$. cereus colonies which were rough in texture, turquoise to peacock blue in colour and surrounded by a greyish zone of egg yolk precipitate. Typical B. cereus colonies were confirmed by Gram staining (Harrigan \& McCance, 1976). The stained smear preparations were examined under oil immersion microscope (Carl Zeiss, West Germany) for spore production. 


\subsubsection{Lactic acid bacteria}

Lactic agar (Merck) and MRS agar (Oxoid CM361) were used for the enumeration of lactic acid bacteria. The media were prepared according to the manufacturer's instructions and poured into petri-dishes for the spread-plate technique. The inoculated plates were incubated at $37^{\circ} \mathrm{C}$ for $48 \mathrm{~h}$. Presumptive lactic acid bacteria were confirmed using the Gram staining test (Harrigan \& McCance, 1976). The stained smear preparations were examined under an oil immersion microscope (Carl Zeiss, West Germany). The colonies that tested Gram positive were recorded as lactic acid bacteria

\subsection{Chemical analyses}

\section{$3.5 .1 \mathrm{pH}$}

The $\mathrm{pH}$ was measured using a combined glass electrode connected to a standard $\mathrm{pH}$-meter DL 25 (Metler - Toledo AG, Switzerland).

\subsubsection{Titratable acidity}

The per cent acid present in the whey was determined by titration by measuring $9 \mathrm{ml}$ of the whey sample in duplicate into $250 \mathrm{ml}$ flasks. To this, $9 \mathrm{ml}$ distilled water and $0.5 \mathrm{ml}$ of phenolphthalein indicator were added and thoroughly mixed. The mixture was then titrated against $0.1 \mathrm{~N}$ sodium hydroxide to a pink colour that marked the end point. The per cent lactic acid present was calculated using the formula:

$\%$ lactic acid of lactic acid $=\mathrm{N} \times \mathrm{V} \times \mathrm{ME}$ of lactic acid $\times 100$

Where: $\mathrm{N} \quad$ is the normality of the sodium hydroxide solution

$\mathrm{V} \quad$ is the volume of sodium hydroxide used to reach the end point

ME is the milli-equivalent of lactic acid

$$
=\underline{\text { molecular weight of lactic acid }} \quad=0.09008
$$




\subsubsection{Fat content of milk}

The Gerber fat test as described by Kosikowski (1978) was used.

\subsubsection{Fat content of cheese}

The method as described by Kosikowski (1978) was used.

\subsubsection{Salt content of cheese}

The method as described by IDF (1972) was used .

\subsubsection{Moisture content}

The method as described by Kosikowski (1978) was used.

\subsection{Statistical Analyses}

Statistical analyses were done using SPSS Version 8.0 for Windows (SPSS Inc., Chicago, USA). Numbers of bacterial counts were converted to $\log _{10} \mathrm{cfu} / \mathrm{ml}$ or $\mathrm{g}$. Means and standard deviations were calculated. The least significant difference between the means was determined. 


\section{CHAPTER 4}

\section{RESULTS}

\subsection{Changes in B. cereus and lactic acid bacteria numbers during the cheese manufacturing}

Table 10 and Figure 8 show changes in B. cereus and lactic acid bacteria numbers in cheese made from milk inoculated with $B$. cereus spores (experimental cheese) and cheese without $B$. cereus spores (control cheese). B. cereus spores survived and germinated into vegetative cells which grew from $10^{2} \mathrm{cfu} / \mathrm{g}$ and reached a maximum of $10^{4} \mathrm{cfu} / \mathrm{g}$ at hooping about $3.5 \mathrm{~h}$ after renneting $(0.023 \mathrm{wk})$. Numbers of $B$. cereus increased by $2.2 \mathrm{log}$ cycles, whereafter they rapidly decreased to less than $1 \times 10^{\mathrm{l}} \mathrm{cfu} / \mathrm{g}$ approximately $16 \mathrm{~h}$ after renneting.

B. cereus did not affect lactic acid bacteria numbers. Lactic acid bacteria numbers increased by $1.7 \log$ cycles from $10^{7}$ to slightly more than $10^{9} \mathrm{cfu} / \mathrm{g}$ and stayed fairly constant throughout the manufacturing and ripening process. B. cereus was not found in the control cheese and there was no significant difference $(p>0.05)$ in the numbers of lactic acid bacteria between the experimental and the control cheese (results not shown on the graph since they would overlap). 
Table 10. Changes in $B$. cereus and lactic acid bacteria numbers during the manufacturing of Gouda cheese

\begin{tabular}{|c|c|c|c|c|c|c|}
\hline $\begin{array}{l}\text { Time } \\
\text { weeks } \\
\text { (wk) }\end{array}$ & $\begin{array}{l}\text { Experime } \\
\left(\log _{10} \mathrm{cfu}\right. \\
(\mathrm{MRS})^{3}\end{array}$ & $\begin{array}{l}\text { tal cheese } \\
(\mathrm{LA})^{3}\end{array}$ & $\mathrm{BC}^{3}$ & $\begin{array}{l}\text { Control } \\
\left(\log _{10} \mathrm{cf}\right. \\
\text { (MRS) }^{3}\end{array}$ & $\begin{array}{l}\text { e } \\
(\mathrm{LA})^{3}\end{array}$ & $\mathrm{BC}^{3}$ \\
\hline 0 & ${ }^{4} \mathrm{~ns}$ & ns & $\begin{array}{l}2.241^{\mathrm{a}} \\
(0.089)\end{array}$ & ns & ns & 0.000 \\
\hline 0.004 & $\begin{array}{c}17.294^{a} \\
{ }^{2}(0.133)\end{array}$ & $\begin{array}{l}7.331^{\mathrm{a}} \\
(0.080)\end{array}$ & $\begin{array}{l}2.361^{\mathrm{a}} \\
(0.093)\end{array}$ & $\begin{array}{l}7.419^{\mathrm{a}} \\
(0.041)\end{array}$ & $\begin{array}{l}7.443^{a} \\
(0.079)\end{array}$ & $\begin{array}{l}0.000 \\
0.000\end{array}$ \\
\hline 0.005 & $\begin{array}{l}7.628^{b} \\
(0.047)\end{array}$ & $\begin{array}{l}7.599^{\mathrm{a}} \\
(0.116)\end{array}$ & $\begin{array}{l}3.466^{\mathrm{b}} \\
(0.046)\end{array}$ & $\begin{array}{l}7.000^{b} \\
(0.115)\end{array}$ & $\begin{array}{l}7.703^{b} \\
(0.072)\end{array}$ & $\begin{array}{l}0.000 \\
0.000\end{array}$ \\
\hline 0.013 & $\begin{array}{l}8.062^{c} \\
(0.106)\end{array}$ & $\begin{array}{l}8.089^{b} \\
(0.161)\end{array}$ & $\begin{array}{l}3.531^{b} \\
(0.026)\end{array}$ & $\begin{array}{l}7.834^{b} \\
(0.073)\end{array}$ & $\begin{array}{l}7.859^{6} \\
(0.066)\end{array}$ & 0.000 \\
\hline 0.023 & $\begin{array}{l}8.171^{b} \\
(0.081)\end{array}$ & $\begin{array}{l}8.113^{b} \\
(0.034)\end{array}$ & $\begin{array}{l}4.414^{c} \\
(0.129)\end{array}$ & $\begin{array}{l}8.146^{c} \\
(0.050)\end{array}$ & $\begin{array}{l}8.149^{c} \\
(0.060)\end{array}$ & $\begin{array}{l}0.000 \\
0.000\end{array}$ \\
\hline 0.095 & $\begin{array}{l}8.796^{\mathrm{d}} \\
(0.129)\end{array}$ & $\begin{array}{l}8.799^{c} \\
(0.146)\end{array}$ & 0.000 & $\begin{array}{l}8.681^{d} \\
(0.126)\end{array}$ & $\begin{array}{l}8.710^{d} \\
(0.127)\end{array}$ & 0.000 \\
\hline 0.238 & $\begin{array}{l}9.033^{\mathrm{de}} \\
(0.051)\end{array}$ & $\begin{array}{l}9.037^{c} \\
(0.072)\end{array}$ & 0.000 & $\begin{array}{l}9.037^{\mathrm{e}} \\
(0.022)\end{array}$ & $\begin{array}{l}9.037^{e} \\
(0.011)\end{array}$ & 0.000 \\
\hline 1 & $\begin{array}{l}9.058^{e} \\
(0.051)\end{array}$ & $\begin{array}{l}9.049^{c} \\
(0.058)\end{array}$ & 0.000 & $\begin{array}{l}9.062^{e} \\
(0.026)\end{array}$ & $\begin{array}{l}9.063^{e} \\
(0.025)\end{array}$ & 0.000 \\
\hline 2 & $\begin{array}{l}9.034^{\mathrm{de}} \\
(0.049)\end{array}$ & $\begin{array}{l}9.025^{\circ} \\
(0.059)\end{array}$ & 0.000 & $\begin{array}{l}9.052^{e} \\
(0.027)\end{array}$ & $\begin{array}{l}9.049^{e} \\
(0.020)\end{array}$ & 0.000 \\
\hline 4 & $\begin{array}{l}9.028^{d e} \\
(0.005)\end{array}$ & $\begin{array}{c}9.031^{\mathrm{c}} \\
(0.024)\end{array}$ & 0.000 & $\begin{array}{l}9.036^{\mathrm{e}} \\
(0.020)\end{array}$ & $\begin{array}{l}9.033^{e} \\
(0.028)\end{array}$ & 0.000 \\
\hline 6 & $\begin{array}{l}9.006^{\text {de }} \\
(0.013)\end{array}$ & $\begin{array}{l}9.001^{c} \\
(0.018)\end{array}$ & 0.000 & $\begin{array}{l}8.987^{\mathrm{e}} \\
(0.020)\end{array}$ & $\begin{array}{l}9.001^{e} \\
(0.021)\end{array}$ & 0.000 \\
\hline
\end{tabular}

1. Means with different superscripts in the same column are significantly different from each other $(\mathrm{p}<0.05)$.

2. Numbers in parentheses are standard deviations

3. Lactic acid bacteria on MRS and lactic agar (LA) and B.cereus, (BC) on Oxoid CM 617 agar

4. ns, not sampled 


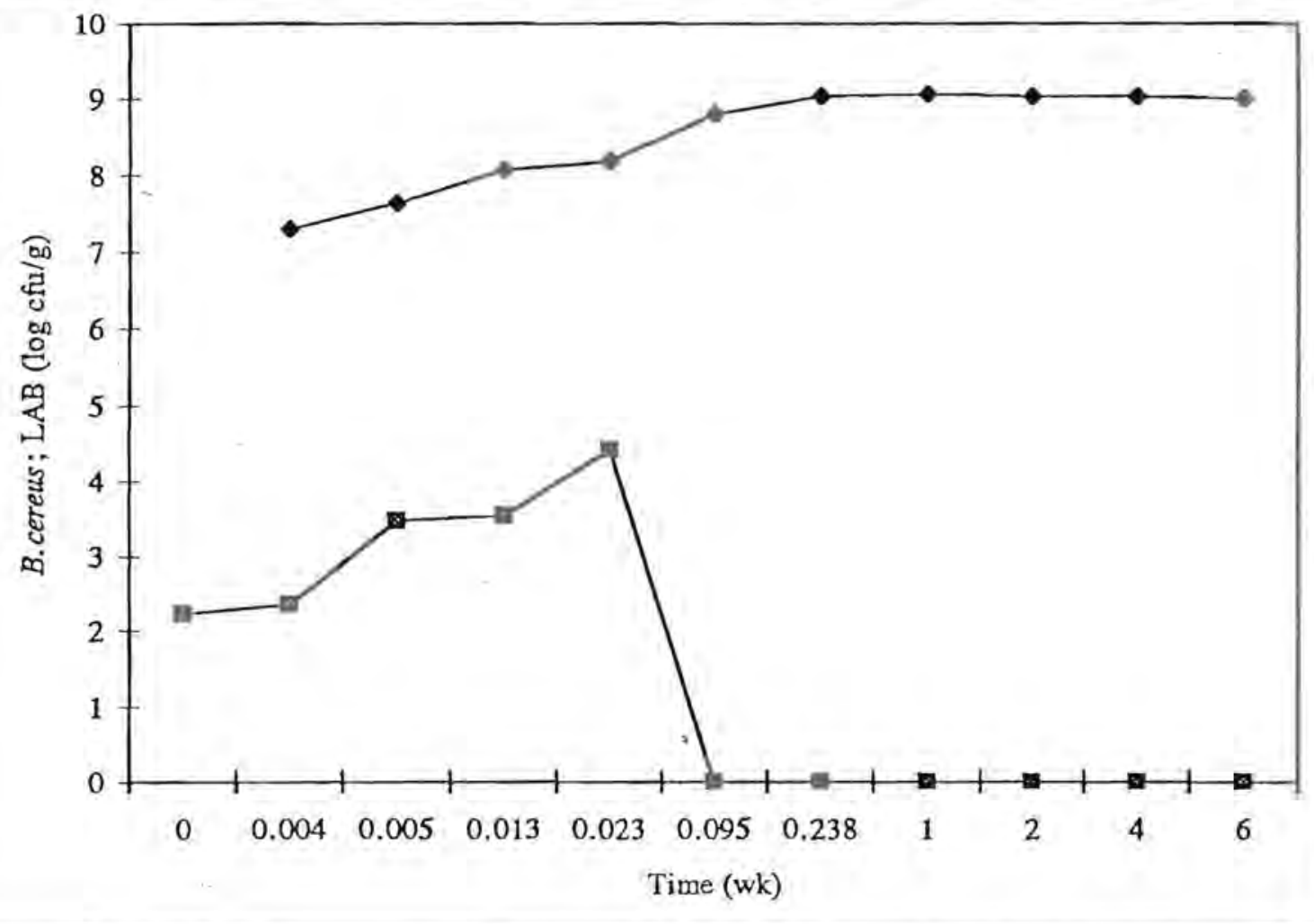

Figure 8. Changes in $B$, cereus ( -1 - ) and Jactic acid bacteria numbers $(-\rightarrow)$

during Gouda type cheese manufacturing from milk inoculated with $B$. cereus spores.

4.2 Changes in $\mathrm{pH}$, B. cereus and lactic acid bacteria numbers during cheese manufacturing

Table 11 and Figure 9 show the changes in $\mathrm{pH}$, and numbers of lactic acid bacteria and $B$. cereus during manufacturing of Gouda type cheese from milk inoculated with $B$. cereus spores. A general decrease in $\mathrm{pH}$ was observed from $\mathrm{pH} 6.6$ to $\mathrm{pH} 5.16$. B. cereus grew from approximately $10^{2} \mathrm{cfu} / \mathrm{g}$ to a maximum of about $10^{4}$ when $\mathrm{pH}$ was $\mathrm{pH} 6.17$ whereafter it decreased sharply to $<10 \mathrm{cfu} / \mathrm{g}$. The lactic acid bacteria increased steadily from approximately $10^{7}$ to slightly over $10^{\circ} \mathrm{cfu} / \mathrm{g}$ and maintained this average count throughout the cheese manufacturing and ripening process. 
Table 11. Changes in $\mathrm{pH}$, numbers of lactic acid bacteria (LAB) and B. cereus during manufacturing of Gouda type cheese from milk inoculated with B. cereus spores.

\begin{tabular}{|c|c|c|c|}
\hline $\begin{array}{l}\text { Time in } \\
\text { weeks (wk) }\end{array}$ & $\overline{\mathrm{pH}}$ & $\begin{array}{l}\text { LAB (MRS) } \\
\left(\log _{10} \mathrm{cfu} / \mathrm{g}\right)\end{array}$ & $\begin{array}{l}\text { B. cereus } \\
\left(\log _{10} \mathrm{cfu} / \mathrm{g}\right)\end{array}$ \\
\hline 0 & $\begin{array}{l}6.6 \\
(0.00)\end{array}$ & ${ }^{3} \mathrm{~ns}$ & $\begin{array}{l}{ }^{1} 2.241^{\mathrm{a}} \\
{ }^{2}(0.089)\end{array}$ \\
\hline 0.004 & $\begin{array}{l}6.43 \\
(0.06)\end{array}$ & $\begin{array}{l}7.293^{\mathrm{a}} \\
(0.133)\end{array}$ & $\begin{array}{l}2.361^{a} \\
(0.093)\end{array}$ \\
\hline 0.005 & $\begin{array}{l}6.43 \\
(0.06)\end{array}$ & $\begin{array}{l}7.628^{b} \\
(0.047)\end{array}$ & $\begin{array}{l}3.466^{b} \\
(0.046)\end{array}$ \\
\hline 0.013 & $\begin{array}{l}6.27 \\
(0.06)\end{array}$ & $\begin{array}{l}8.062^{c} \\
(0.106)\end{array}$ & $\begin{array}{l}3.531^{\mathrm{b}} \\
(0.026)\end{array}$ \\
\hline 0.023 & $\begin{array}{l}6.17 \\
(0.06)\end{array}$ & $\begin{array}{l}8.171^{d} \\
(0.081)\end{array}$ & $\begin{array}{l}4.414^{c} \\
(0.129)\end{array}$ \\
\hline 0.095 & $\begin{array}{l}6.13 \\
(0.06)\end{array}$ & $8.796^{\mathrm{d}}$ & 0.000 \\
\hline 0.238 & $\begin{array}{l}5.17 \\
(0.01)\end{array}$ & $9.033^{\text {de }}$ & 0.000 \\
\hline 1 & $\begin{array}{l}5.16 \\
(0.01)\end{array}$ & $9.058^{e}$ & 0.000 \\
\hline 2 & $\begin{array}{l}5.16 \\
(0.01)\end{array}$ & $9.034^{\text {de }}$ & 0.000 \\
\hline 4 & $\begin{array}{l}5.16 \\
(0.01)\end{array}$ & $9.028^{\mathrm{de}}$ & 0.000 \\
\hline 6 & $\begin{array}{l}5.16 \\
(0.01)\end{array}$ & $9.006^{\text {de }}$ & 0.000 \\
\hline
\end{tabular}

1. Means with different superscripts in the same column are significantly different from each other $(\mathrm{p}<0.05)$

2. Numbers in parentheses are standard deviations

3. ns, not sampled 


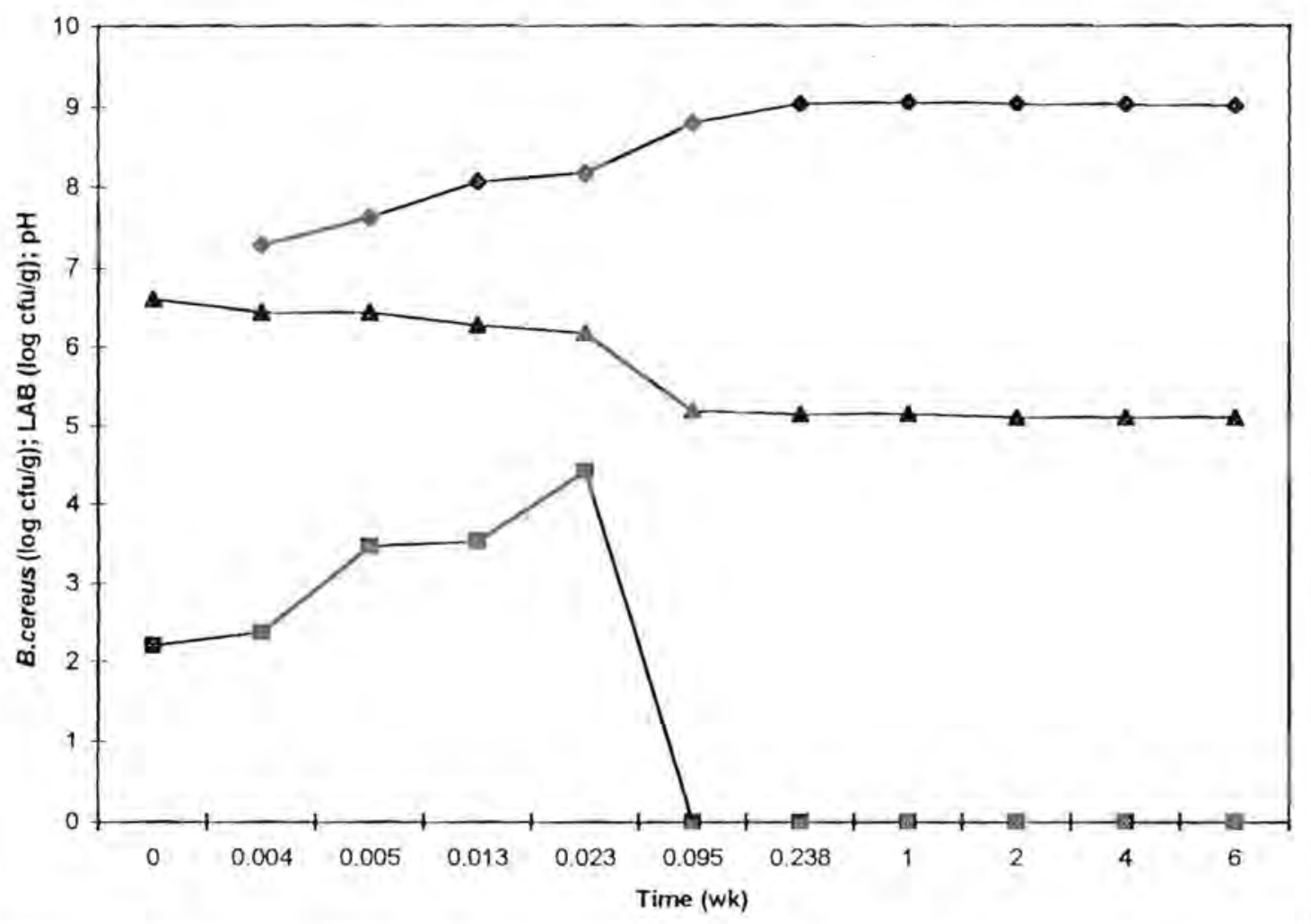

Figure 9. Changes in $\mathrm{pH}(-\Delta-)$; numbers of lactic acid bacteria ) and B. cereus $\left(-{ }^{-}-\right)$during manufacture of Gouda type cheese from milk inoculated with B. cereus spores.

Table 12 and Figure 10 show changes in $\mathrm{pH}$ and numbers of lactic acid bacteria in cheese without B. cereus spores (control cheese). The $\mathrm{pH}$ decreased from $\mathrm{pH} 6.60$ to $\mathrm{pH} 5.15$. Lactic acid bacteria grew steadily from $10^{7}$ to slightly over $10^{9}(1.7 \log$ cycles $)$ and maintained the maximum count throughout ripening, B. cereus was not found in the control cheese $(<10 / g)$ 
Table 12. Changes in $\mathrm{pH}$ and numbers of lactic acid bacteria during the manufacture of control Gouda type cheese (no B. cereus spores added)

\begin{tabular}{|c|c|c|}
\hline $\begin{array}{c}\text { Time in weeks } \\
\text { (wk) }\end{array}$ & $\mathrm{pH}$ & $\begin{array}{l}\text { LAB on MRS } \\
\left(\log _{10} \mathrm{cfu} / \mathrm{g}\right)\end{array}$ \\
\hline 0 & $\begin{array}{c}6.60 \\
(0.00)\end{array}$ & ${ }^{3} \mathrm{~ns}$ \\
\hline 0.004 & $\begin{array}{r}6.43 \\
(0.06)\end{array}$ & $\begin{array}{l}{ }^{17} 7.419^{\mathrm{a}} \\
{ }^{2}(0.041)\end{array}$ \\
\hline 0.005 & $\begin{array}{r}6.40 \\
(0.00)\end{array}$ & $\begin{array}{l}7.000^{b} \\
(0.115)\end{array}$ \\
\hline 0.013 & $\begin{array}{r}6.30 \\
(0.00)\end{array}$ & $\begin{array}{l}7.834^{b} \\
(0.073)\end{array}$ \\
\hline 0.023 & $\begin{array}{c}6.15 \\
(0.07)\end{array}$ & $\begin{array}{l}8.146^{c} \\
(0.050)\end{array}$ \\
\hline 0.095 & $\begin{array}{c}6.11 \\
(0.01)\end{array}$ & $\begin{array}{l}8.681^{d} \\
(0.126)\end{array}$ \\
\hline 0.238 & $\begin{array}{r}5.19 \\
(0.01)\end{array}$ & $\begin{array}{l}9.037^{e} \\
(0.022)\end{array}$ \\
\hline 1 & $\begin{array}{l}5.17 \\
(0.01)\end{array}$ & $\begin{array}{l}9.062^{e} \\
(0.026)\end{array}$ \\
\hline 2 & $\begin{array}{l}5.16 \\
(0.01)\end{array}$ & $\begin{array}{l}9.052^{\mathrm{e}} \\
(0.027)\end{array}$ \\
\hline 4 & $\begin{array}{c}5.15 \\
(0.01)\end{array}$ & $\begin{array}{l}9.036^{\mathrm{e}} \\
(0.020)\end{array}$ \\
\hline 6 & $\begin{array}{c}5.15 \\
(0.01)\end{array}$ & $\begin{array}{l}8.987^{c} \\
(0.020)\end{array}$ \\
\hline
\end{tabular}

1. LAB, lactic acid bacteria on MRS

2. Means with different superscripts in the same column are significantly different from each other $(p<0.05)$

3. Numbers in parentheses are standard deviations

4. ns, not sampled 


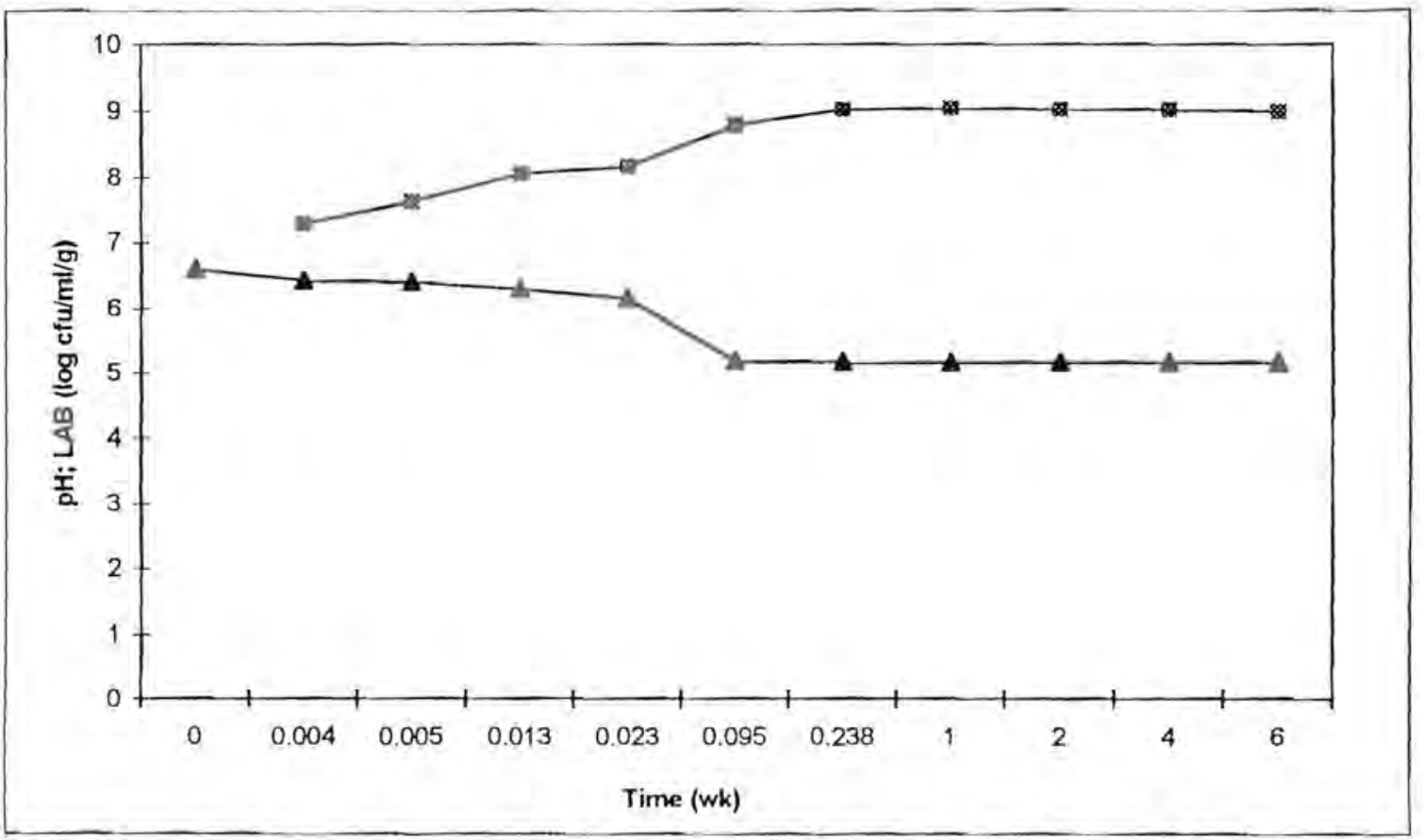

Figure 10. Changes in $\mathrm{pH}(-\mathbf{A}$ ) and numbers of lactic acid bacteria $(-\bullet)$ during manufacturing of control Gouda type cheese (milk not inoculated with B. cereus) 


\subsection{Chemical analyses of the cheese at 6 weeks}

Chemical analysis were done at 6 weeks mainly to check the quality of the cheese. Table 13 shows the $\mathrm{pH}, \%$ salt content, moisture content and \% fat content of the experimental and the control cheese at 6 weeks.

Table 13. Means of $\mathrm{pH}, \%$ salt content, moisture content and $\%$ fat content of the experimental and control cheese at 6 weeks

\begin{tabular}{|l|l|l|}
\hline Analysis & Experimental cheese & Control cheese \\
\hline $\mathrm{pH}$ & 5,16 & 5,15 \\
\hline$\%$ Fat content & 31,2 & 30,0 \\
\hline Moisture content & 40,2 & 39,8 \\
\hline$\%$ Salt content & 2,0 & 1,88 \\
\hline \% salt in moisture & 4,74 & 4,51 \\
\hline$\%$ fat in dry matter & 52,22 & 49,83 \\
\hline
\end{tabular}




\section{Colony morphology of $B$. cereus}

Typical B. cereus colonies with a dry rough surface and a blue-purple base surrounded by a ring of dense precipitate were isolated from the curd and whey during the early stages of the cheese manufacturing

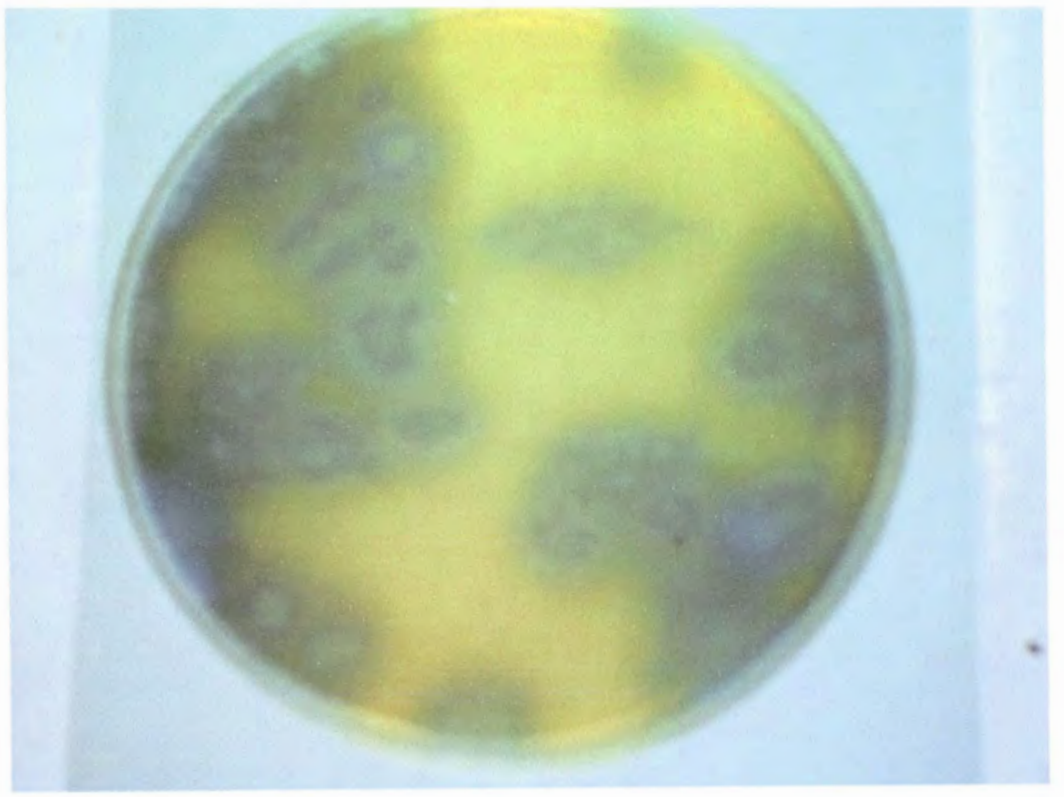

Figure 11 Colony morphology of $B$. cereus colonies grown on $B$. cereus selective agar 


\section{CHAPTER 5}

\section{DISCUSSION}

Vegetative cells of $B$. cereus are easily inactivated by heat, but the spores are activated by the heat treatment of pasteurisation, which triggers their germination and outgrowth (Andersson et al, 1995; Meer et al, 1991; Driessen, 1992). Meer et al (1991) found that more than $95 \%$ of the spores in milk were activated at pasteurisation temperature and germinated in the milk. According to Driessen (1992) the extent to which the spores grow out in milk is dependent on the species or even the variant of the species and on the condition of storage of milk. In a study by Wong et al (1988) vegetative cells of B.cereus were killed or inactivated within $40 \mathrm{~min}$ in fermented milk while about $31 \%$ of spores survived the $7 \mathrm{~d}$ test period. In cheese milk inoculated with $10^{2} \mathrm{~B}$. cereus spores per $\mathrm{ml}$ of milk in the present study, $B$. cereus multiplied during cheese-making to a maximum of $10^{4}$ cfu per g at hooping, i.e. after about $3 \mathrm{~h} 50 \mathrm{~min}$. After pressing (approximately $16 \mathrm{~h}$ after renneting) $B$. cereus numbers were reduced to less than $1 \times 10^{1} \mathrm{cfu} / \mathrm{g}$ of cheese curd. The level of vegetative cells of $B$. cereus did not exceed $10^{5}$ per $\mathrm{ml}$ or per gram, a number which has been reported to cause illness (Johnson, 1984). The results of the present study are in contrast to those of Langeveld \& Cuperus (1992) who found that only a minority of B. cereus spores present in milk before pasteurisation both germinated and grew quickly enough to be important for deterioration of the product.

The initial growth of $B$. cereus was expected because after pasteurisation the milk was free from other competitor micro-organisms and the $B$. cereus spores were activated by the heat treatment (Andersson et al, 1995) and conditions were still quite favourable for their growth.

$B$. cereus grew nearly at the same rate as the lactic acid bacteria during the early stages of lactic acid fermentation until the $\mathrm{LAB}$ reached numbers of $10^{8} / \mathrm{g}$ and the $\mathrm{pH}$ dropped to below 6.17. Thereafter the numbers of $B$. cereus decreased rapidly. Work by Wong \& Chen (1988) on germination and growth of $B$. cereus in non-fat milk with added lactic acid bacteria also showed that $B$. cereus was not affected by lactic acid bacteria at the beginning of the fermentation process, but was affected strongly with continued fermentation. Killing or 
inactivation of vegetative $B$. cereus cells at $\mathrm{pH}$ below 6.17 may not be attributed to reduction in $\mathrm{pH}$ and lactic acid production only but to a number of factors which act synergistically such as substrate competition, changes in oxidation-reduction potential and production of antimicobial agents (Wong et al 1988). According to Wong et al (1988) antimicrobial agents such as hydrogen peroxide, formate, acetate or lactate enhanced the inhibitory activity of lactic acid bacteria.

When considerable lactose had been fermented to lactic acid and the $\mathrm{pH}$ reduced to $\mathrm{pH} 5.2$, growth of $B$. cereus was inhibited strongly. The reduction of $B$. cereus at $\mathrm{pH}$ lower than 6.1 is in accordance with the results found by Driessen (1992) during manufacture of yoghurt. As the acidity increased vegetative cells of $B$. cereus failed to survive, the counts went down from $10^{4}$ to less than $1 \times 10^{1} \mathrm{cfu} / \mathrm{g}$ of cheese curd. At this stage the condition of the cheese curd, particularly low moisture content $\left(\mathrm{a}_{\mathrm{w}}\right)$, lack of oxygen (low Eh), high salt concentration and depleted lactose content combined with high acid content may have inhibited the growth of B. cereus (Chapman \& Sharpe, 1981). However, it has been previously demonstrated that inhibition of pathogens by lactic acid bacteria is not only dependent on acid production and decreased pH (Frank, Marth \& Olson, 1978).

At hooping (moulding) the numbers of lactic acid bacteria surged well ahead of the numbers of $B$. cereus. After pressing $B$. cereus was not isolated, however lactic acid bacteria remained flourishing throughout the manufacturing and ripening process reaching numbers as high as $10^{9} \mathrm{cfu} / \mathrm{g}$. According to Kosikowski (1978) bacterial numbers of $10^{8}$ to $10^{9} \mathrm{cfu} / \mathrm{g}$ are enough to enhance cheese ripening. Both experimental and control cheese thus contained enough lactic acid bacterial cells $\left(10^{9} \mathrm{cfu} / \mathrm{g}\right)$ to accomplish ripening of the cheese. Analysis of variance showed no significant difference $(p>0.05)$ in the isolation rate of lactic acid bacteria on the two media, lactic agar and MRS agar.

In the present study the increase in the titratable acidity was not significantly correlated with changes in $\mathrm{pH}$. According to Scott (1986) $\mathrm{pH}$ readings measure hydrogen ion activity in the milk, the coagulum, the curds and finally the solid cheese, whereas the titratable acidity measurements are made on liquids (milk and whey). Because of the differences between the 
systems being measured, there was no correlation between $\mathrm{pH}$ readings and titratable acidity, so the cheese manufacturer cannot switch from one form of measurement to another.

The moisture content of the cheese was satisfactory. According to Kosikwoski (1978) a maximum of $42 \%$ moisture is allowed in washed curd cheese. The high moisture content enhance ripening. The salt content and the fat content of the cheese were acceptable in a way that they are comparable to those mentioned in the literature which range from $1.5-2.2 \%$ salt and $30 \%$ fat (Kosikwoski, 1978). Salt tend to play a role in cheese-making mainly to restore the calcium balance of the cheese milk, also by controlling the moisture content of the cheese, through aiding in whey expulsion. Salt also tend to increase the elasticity of the curd by forming a colloidal calcium phosphate and it also inhibits growth of microorganisms (Kosikowski, 1978). 


\section{CHAPTER 6}

\section{CONCLUSIONS AND RECOMMENDATIONS}

B. cereus spores germinated and the vegetative cells multiplied during Gouda cheese manufacturing. The level of vegetative cells which was reached during cheese manufacturing was below the level of $10^{\mathrm{s}} \mathrm{cfu} / \mathrm{g}$ which was reported to cause illness or significant spoilage of milk and milk products. Growth of B. cereus during Gouda cheese manufacturing will be inhibited by $\mathrm{pH}$, high lactic acid levels or by other factors such as hydrogen peroxide production, nutrient reduction, decreased lactose content or a decrease in the redox potential (Wong \& Chen, 1988).

Lactic acid bacteria present in the curd continued to multiply in the maturing cheese and reached levels of $10^{\circ}$ per gram in cheese of 6 weeks old. Growth of B. cereus was not affected by growth of the lactic acid bacteria during the early stages of the cheese-making process, but their continued growth resulted in a decrease in the numbers of $B$. cereus later in the cheese-making process until they could no longer be isolated from the cheese.

Lactic acid bacteria inhibit the growth of pathogens and spoilage organisms in milk and milk products and contribute remarkably to texture and flavour development of the cheese. The cheese manufacturer requires simple, rapid, sensitive and low cost methods for assessing the presence of pathogenic and spoilage organisms or their toxins and by-products in Gouda type cheese.

No viable cells of $B$. cereus were found in the cheese at the end of the manufacturing process in particular because of decreased lactose content, low $\mathrm{a}_{w}$, low Eh, high lactic acid content and reduced $\mathrm{pH}$. Therefore, it can be concluded that $B$. cereus was able to grow during early stages of cheese manufacturing but was not able to survive during the final stages of the manufacturing process and ripening of the cheese. 
With a view to future research in this field, it is recommended that the effects of major fermentative organic acids on growth and germination of vegetative cells and endospores of $B$. cereus be studied. 


\section{REFERENCES}

AHMED-A-H., MOUSTAFA, K. \& MARCH, E. H., 1983. Incidence of Bacillus cereus in milk and some milk products. Journal of Food Protection 46, 126-128.

ANDERSSON, A., RONNER, U. \& GRANUM, P., 1995. What problems does the food industry have with spore-forming pathogens, Bacillus cereus and Clostridium perfringens? International Journal of Food Microbiology 28, 145-155.

ASANUMA, S., TAKANA, H. \& YATAZAWA, M., 1979. Rhizoplane microorganisms of rice seedlings as examined by scanning electron microscopy. Soil Science \& Plant Nutrition $25,539-551$.

BECKER, H. \& TERPIAN, G., 1992. Importance of Bacillus cereus in infant foods and powdered milk products. Bulletin of the Internationational Dairy Federation 287, 18-19.

BECKER, H. \& VAN, E. H. W., 1983. Survival of Salmonella spp., Staphylococcus aureus, and Bacillus cereus in "Advocaat." Journal of Food Protection 46, 98-99.

BEUCHAT, L. R., CLAVERO, M. R. S. \& JAQUETTE, C. B., 1997. Effects of Nisin and temperature on survival, growth and enterotoxin production characteristics of psychotrophic Bacillus cereus in beef gravy. Applied and Enviromental Microbiology 63, 1953-1958.

BJORCK, 1., 1993. Preservation of raw milk by the Lactoperoxidase system legal situation. Indigenous antimicrobial agents of milk - Recent developments. Proceedings of the International Dairy Federation Seminar held in Upala Sweeden, 31 August \& 1 September 1993. Brussels : International Dairy Federation. pp 211-214.

BLAKEY. L. J. \& PRIEST, F. G., 1980. The occurrence of Bacillus cereus in some dried foods including pulses and cereals. Journal Applied Bacteriology 48, 297-302. 
BRYAN, F. L., 1972. Emerging foodborne diseases. II. Factors that contribute to outbreaks and their control. Journal Milk Food Technology 35, 632-638.

CERF, O. \& BERGERE, J. L., 1992. Heat resistance of Bacillus cereus spores. Bulletin of the International Dairy Federation 287, 17.

CHAPMAN, H. R. \& SHARPE, M. E., 1981. Microbiology of cheese. In: Robinson R. K., (eds.). Dairy Microbiology. The microbiology of milk products. $1^{\text {st }}$ edition. Vol. 2. London and New York: Elsevier Applied Publishers Inc, pp. 157-243.

CHRISTIANSON, A., 1992. Enterotoxin production in milk by Bacillus cereus: a comparison of methods for toxin detection. Bulletin of the International Dairy Federation $287,54-56$.

CHUNG, T. M. \& CANNON, R. Y., 1971. Psychrotrophic sporeforming bacteria in raw milk supplies. Journal of Dairy Science 54, 448.

COGAN, T. M., 1995. Flavour production by dairy starter cultures. Journal of Applied Bacteriology; Symposium Supplement 79, 495-645.

COGAN, T. M., PEITERSEN, N. \& SELLARS, R. L., 1991. Starter systems. Bulletin of the International Dairy Fedaration 263, 16-23.

CRIELLY, E. M., LOGAN, N. A. \& ANDERTON, A., 1992. Studies of the Bacillus cereus flora of milk and milk products. Bulletin of the International dairy Federation 287, 22.

DAESCHEL, M. A., 1989. Antimicrobial substances from lactic acid bacteria for use as food preservatives. Food Technology 43, (1) 164-166. 
DAVIES, F. L., 1977. The role of various milk fractions and importance of somatic cells in the formation of germinants for Bacillus cereus when milk is pasteurised. Journal of Dairy Research 44, 555-568.

DAVIES, F. L. \& WILKINSON, G., 1973, Bacillus cereus in milk and dairy products. In: Hobbs, B. C. \& Christian, J.H.B. (eds). The microbial safety of food. Proceedings of the 8th International Symposium on Food Microbiology. London: Academic Press pp 57-67.

DRIESSEN, F. M., 1992. Importance of Bacillus cereus in fermented milks and processed non-fermented dairy foods. Bulletin of the International Dairy Federation 287, 11-15.

ECKNER, K. F., ROBERTS, R. F., STRANTZ \& ZOTTOLA, A., 1990. Characterisation and behaviour of Salmonella javiana during manufacture of Mozzarella-type cheese. Journal of Food Protection 53, 462-464.

ENAN, G., EL-ESSAWY, A. A., UYTTENDALE, M \& DEBEVERE, J., 1996. Antibacterial activity of Lactobacillus UGI isolated from dry sausage: characterisation, production and bacterial action of plantaricin UGI. International Journal of Food Microbiology 30, 189-21.

FRANK, J. F., MARTH, E. H. \& OLSON, N. F., 1978. Behavior of enteropathogenic Escherichia coli during manufacture and ripening of brick cheese. Journal of Food Protection 41, 111-115.

FRANKLAND, G. C. \& FRANKLAND, P. F., 1974. Bacillus cereus. In: Buchanan, R. E. \& Gibbson, N. E. (eds). Bergey's Manual of Determinative Bacteriology, 8th edition. Baltimore: The Williams \& Wilkins Company. pp 534-535.

FORSS, D. A. \& PATTON, S., 1966. Mechanisms of fermentation of aroma compounds in milk and milk products. Journal of Dairy Science 49,89 . 
GOEPFERT, J. M., SPIRA, W. M., GLATZ, B. A. \& KIM, H.U., 1972. Pathogenicity of Bacillus cereus, In: Hobbs, B. C. \& Christian, J.H.B. (eds). The microbial safety of food. Proceedings of the 8th International Symposium on Food Microbiology. London: Academic Press pp 69-75.

GOEPFERT, J. M., SPIRA, M. \& KIM, U., 1992. Bacillus cereus: Food poisoning organism. A review. Journal Milk Food Technology 35, 213-223.

GOULD, G. W., 1993. Formation, germination and enumeration of Bacillus cereus spores. Bulletin of the International Dairy Federation 287, 11-15.

GRANUM, P., 1994. Bacillus cereus and its toxins. Journal of Applied Bacteriology. Symposium Supplement 76, 615-665.

GRIFFITHS, M. W., 1992. Bacillus cereus in liquid milk. Bulletin of International Dairy Federation 287, 18.

HARRIGAN, W. F. \& McCANCE, C., 1976. Laboratory methods in food and dairy microbiology. London: Academic Press.

IDF, 1972. Determination of chloride content (Reference method). International Dairy Federation Standard 17A.

IDF, 1990. Behaviour of pathogens in cheese. International Dairy Federation (IDF). DOC $122,3-18$.

IDF, 1992. Preparation of samples and dilutions for microbiological examination. International Dairy Federation Standard 122B. pp 1 - 4. 
IN'T VELD, P. H., SOENTARO, P. S. \& NOTERMANS, S. H., 1993. Properties of Bacillus cereus spores in reference materials prepared from artificially contaminated spray dried milk. International Journal of Food Microbiology 20, 23-36.

JAY, J., M., 1982. Antimicrobial properties of diacetyl. Applied and Enviromental Microbiology 44, $525-532$.

JAY, J. M., 1992. Modern food microbiology, 4th edition. New York: Chapman and Hall $701 \mathrm{p}$.

JOHNSON, K. M., 1984. Bacillus cereus food borne illness: an update. Journal of Food Protection 476, 145-153.

JOHNSON, K. M., NELSON, C. L. \& BUSTA, F, F,, 1982. Germination and heat resistance of Bacillus cereus spores from strains associated with diarrheal and emetic foodborne illnesses. Journal of Food Science 47, 1268-1271.

JOHNSON, M., STEELE, J., BROADBENT, J. \& WEIMER, B., 1998. Manufacture of Gouda cheese and flavour development in reduced fat cheddar cheese. The Australian Journal of Dairy Technology 53, 67-69.

JOHNSON, E., NELSON, J. H. \& JOHNSON, M., 1990. Microbiological safety of cheese made from heat-treated milk, Part 1: Executive survey introduction and history. Journal of Food Protection 53, 441-452.

KALOGRIDOU-VASSILLADOU, D. \& TSIANTAS, A., 1992. Sources of contamination by Bacillus cereus in the dairy factory. Bulletin of the International Dairy Federation 287, 25.

KANAWJIA, S. K., RAJESH, P. \& SINGH, S., 1991, Research in Gouda cheese technology: A review. Indian Journal Dairy Science 44, 485-495. 
KANDLER, O. \& WEISS, N., 1986. Genus Lactobacillus. In: J. G. (eds) Bergey's Manual of Systematic Bacteriology: VoI. 2. Baltimore: Williams \& Wilkins Company. pp 1209 -1234.

KOSIKOWSKI, F., 1978. Cheese and fermented milk foods. 2nd edition. New York: F.V. Kosikowski and Associates. pp 16-36, 281-282,

KEENAN, T. W., 1968. Metabolism of volatile compounds by lactic starter culture microorganisms: A review. Journal Dairy Science 51, 1561-1567.

KRAMER, J. M. \& GILBERT, R. J., 1989. Bacillus cereus and other Bacillus species, In: Doyle M. P. (editor) Food-borne Bacterial Pathogens. New York: Marcel Dekker, pp $21-70$.

LANGSRUD \& REINBOLD, G. W., 1973. Flavour development and microbiology of Swiss cheese: A review, Journal of Milk Food Technology 37, 26-41.

LANGEVELD, L. P. M. \& CUPERUS, F., 1992. Aspects regarding the application of a predictive model of Bacillus cereus in pasteurized milk. Bulletin of the International Dairy Federation 287, 6-10.

LODI, R. \& MALASPINA, P., 1992. Behaviour of Bacillus cereus in the presence of lactic acid bacteria in fresh cheeses. Bulletin of the International Dairy Federation 287, 29.

MACRAE, R., ROBINSON, R. K. \& SADLER, M. J., 1993. Encyclopaedia of food science, food technology and nutrition. New York: Academic Press.

MARQUIS, R. E., SIM, J. \& SHIN, S. Y., 1994. Molecular mechanism of resistance to heat and oxidative damage. Journal of Applied Bacteriology Symposium Supplement 76, $40 \mathrm{~S}-48 \mathrm{~S}$. 
MEER, R. R., BAKER, J., BODYFELT, F. W. \& GRIFFITHS, M. W., 1991. Psychrotrophic Bacillus spp. in fluid milk products: A review. Journal of Food Protection 54, 969-979.

MIKOLAJCIK, E. M., 1978. Psychrotrophic sporeformers. A possible keeping quality problem in market milk. American Dairy Reviews. Manufactured milk products supplement. 41,34D.

MIKOLAJCIK, E. M., KEARNEY, J. W. \& KRISTOFFERSEN, 1973. Fate of Bacillus cereus in cultured and direct acidified skim milk and cheddar cheese. Journal of Milk Food Technology 36, 317-320.

MORRIS, H. A., 1978. Cheese ripening research - trends and perspectives. Journal of Dairy Science 61, 1198-1203.

MOSSEL, D. A., KOOPMAN, M. J. \& JONGERIUS, E., 1967. Enumeration of Bacillus cereus in Foods. Applied Microbiology 15, 650-653.

NAKAJMA, H., TOYODA, S., KITAMURA \& AHIKO, K., 1991. Accelerated ripening of Gouda cheese: Direct inoculation of a lactose-negative mutant of Lactococcus lactis subsp. cremoris into cheese milk. Milchwissenschaft 46, 8-10.

NOTERMANS, S., DUFRENNE, J., TEUNS, P., BEUMER, R., GIFFEL, M. \& WEEM, P., 1997. A risk assessment study of Bacillus cereus present in pasteurised milk. Food Microbiology 14, 143-151.

OVERCAST, W. W. \& ATMARAM, K., 1974. The role of Bacillus cereus in sweet curdling or fluid milk. Journal Milk Food Technology 37, 233-236. 
RANGASAMY, P. N., IYER, M. \& ROGINSKI, H., 1994. Isolation and characterisation of Bacillus cereus in milk and dairy products manufactured in Victoria. International Journal of Dairy Technology 49, 93-95.

REFAI, M. K., 1979. Manual of food quality control. 4: Microbiological analysis, Rome: Food and Agricultural Organization of the United Nations.

ROBERTS, T. A. \& SKINNER, F. A., 1983, Food Microbiology: Advances and prospects. New York: Academic Press Inc. pp. 131-148.

RODRIQUEZ, M. H. \& BARRETT, E. L., 1986. Changes in microbial populations and growth of Bacillus cereus during storage of reconstituted dry milk. Journal of Food Protection 49, 680-686.

ROSENTHAL, I., 1991. Milk and dairy products. New York: Balabala Publishers. pp 113135.

SCHRODER, M. \& BLAND, M. A., 1984. Effect of pasteurisation temperature on keeping quality of whole milk. Journal of Dairy Science 55, 1405-1409.

SCOTT, R., 1986. Cheesemaking practice. 2nd edition. New York: Elsevier Applied Science Publishers pp 24-245.

SETLOW, P., 1994. Mechanisms which contribute to long-term survival of spores of Bacillus species. Journal of Applied Bacteriology Symposium supplement 76, 495-605.

SHEHATA, T. E. \& COLLINS B. E., 1972. Sporulation and heat resistance of strains of Bacillus. Journal of Dairy Science 55, $1405-1409$. 
SIMS, G., GLENISTER, D., BROCKELEHURST, T. \& LUND, B. L., 1989. Survival and growth of food poisoning bacteria following inoculation into cottage cheese varieties. International Journal of Food Microbiology 9, 173-195.

SLY, T. \& ROSS, E., 1982. Chinese foods: Relationship between hygiene and bacterial flora. Journal food Protection 45, 115-118.

SPAHR, U. \& URL, B., 1994. Behavior of pathogenic bacteria in cheese: A synopsis of experimental data. Bulletin of the International Dairy Federation 298, 2-13.

STADHOUDERS, I. \& BEUMER, R. R., 1993. Actual and potential applications of the natural antimicrobial agents of milk in the dairy industry. Indigenous antimicrobial agents of milk-Recent developments. Proceedings of the International Dairy Federation Seminar held in Uppsala Sweden, 31 August to 1 September 1993. Brussels: International Dairy Federation. pp. 175-197.

ST ADHOUDERS, J., HUP, G. \& LANGEVELD, P. L. M., 1980. Some observation on the germination, heat resistance and outgrowth of fast germinating and slow-germinating spores of Bacillus cereus in pasteurized milk. Netherlands Milk Dairy Journal 34, 215-228.

STANIER, R., ADELBERG, E. \& INGRAHAM, J., 1979. General Microbiology. $4^{\text {th }}$ edition. London: The MacMillan Press Ltd., pp 648-788.

STEELE, J. E. \& STILES, M. E., 1981. Food poisoning potential of artificially contaminated vacuum packed sliced ham in sandwiches. Journal Food protection 44, 430434.

STONE, J. M. \& ROWLANDS, A., 1952. "Broken" or "bitty" cream in raw and pasteurised milk. Journal of Dairy Research 19, 51-62. 
SZABO, R. A., TODD, E. C. D. \& RAYMAN, M. K., 1984. Twenty four hour isolation and confirmation of Bacillus cereus in foods. Journal of Food Protection 47, 856-860.

TAMIME, A. Y., 1981. Microbiology of starter cultures. In; Robinson, R. K., (eds.) Dairy microbiology. The microbiology of milk products. $1^{\text {st }}$ edition. Vol. 2. London and New York: Elsevier Applied Publishing Inc. pp. 113-128.

TOMITA, M., TAGUCHI, R. \& IKEZAWA, H., 1991. Sphigomyelinase of Bacillus cereus as a bacterial hemolysin. Journal of Toxicology. Toxin Reviews 10, 169-207.

TOYODA, S., KITAMURA \& KAHIKO, 1991. Accelerated ripening of Gouda cheese: Direct inoculation of a lactose-negative mutant of Lactococcus lactis subsp. cremoris into cheese milk. Milchwissenchaft 46, 8-10.

WEBB, B. H., JOHSON, A. J. \& ALFORD, J. A., 1988. Dutch type varieties, In: cheese Chemistry, Physics and Microbiology, Vol. 2. New York: Elsevier Applied Publishing Co.

WESTHOFF, D. C. \& DOUGHERTY, S. L., 1981. Characterisation of Bacillus species isolated from spoiled ultrahigh temperature processed milk. Journal Dairy Science 64, 572580.

WONG, H. \& CHEN, Y., 1988. Effects of lactic acid bacteria and organic acids on growth and germination of Bacillus cereus. Applied and Environmental Microbiology 54, 21792184

WONG, H. C., CHEN, L.Y. \& CHEN, C. L., 1988. Growth, germination and toxigenic activity of Bacillus cereus in milk products. Journal of Food Protection 51, 707-710.

ZOTTOLA, A. \& SMITH, B., 1991. Pathogens in cheese. Food Microbiology 8, 171-182. 
APPENDIX 1 CHEESE MANUFACTURING RECORDS 


\section{CHEESE MANUFACTURING RECORD}

CONTROL CHEESE A

Type of Cheese: GOUDA

Date: $2 / 7 / 98$

Milk: \% Fat:

3.7

Acidity $(\%) 0,15$

Starter: Type $\mathrm{CHN}_{22}$

\begin{tabular}{|c|c|c|c|c|c|c|c|}
\hline \multirow{2}{*}{\multicolumn{2}{|c|}{ Item/Action }} & Quantity & $\%$ Fat & Temp $\left({ }^{\circ} \mathrm{C}\right)$ & Acidity & \multirow{2}{*}{\multicolumn{2}{|c|}{ Time }} \\
\hline & & & & & $\%$ & & \\
\hline Milk & & $100 \ell$ & 3.7 & & 0.15 & 6.6 & \\
\hline Starter & $0.75 \%$ & $750 \mathrm{ml}$ & & & & & \\
\hline \multicolumn{2}{|c|}{ Cheese milk } & $100 \ell$ & & 31 & & & 2.00 \\
\hline \multicolumn{2}{|c|}{ Colouring $1,25 \mathrm{ml} / 100 \ell$} & $10 \mathrm{ml}$ & & & & & 2.00 \\
\hline $\mathrm{CaCl}_{2}$ & $50 \mathrm{ml} / 100 \ell$ & $50 \mathrm{ml}$ & & & & & 2.00 \\
\hline Rennet & $3 \mathrm{ml} / 100 \ell$ & $30 \mathrm{ml}$ & & 31 & & & 2.00 \\
\hline \multicolumn{2}{|l|}{ Cut } & & & 31 & 0,12 & 6,4 & 2.40 \\
\hline \multicolumn{2}{|c|}{ First removal of whey } & & & 31 & & & 2.55 \\
\hline \multicolumn{2}{|c|}{ Water added } & & & 31 & 0,10 & 6,4 & 3.05 \\
\hline \multicolumn{2}{|c|}{ Start heating } & & & 31 & & & 3.15 \\
\hline
\end{tabular}

Acid development: 1

3

End heating

Remove half of whey

Final whey removal

Cheddaring: start

end

Milling

Salting

Pressing 


\section{CHEESE MANUFACTURING RECORD}

\section{EXPERIMENTAL CHEESE A}

Type of Cheese: GOUDA

Milk: \% Fat:

3.7

Starter:Type
Date: $2 / 7 / 98$

Acidity $(\%) 0,15$

$\mathrm{CHN}_{22}$

\begin{tabular}{|c|c|c|c|c|c|c|c|}
\hline \multicolumn{2}{|c|}{ Item/Action } & Quantity ? & $\%$ Fat & \multirow[t]{2}{*}{ Temp $\left({ }^{\circ} \mathrm{C}\right)$} & \multicolumn{2}{|l|}{ Acidity } & Time \\
\hline Milk & & $100 \ell$ & 3.7 & & 0,15 & 6,6 & \\
\hline Starter & $0,75 \%$ & $750 \mathrm{ml}$ & & & & & \\
\hline Cheese $n$ & nilk & $100 \ell$ & & 31 & & & \\
\hline Colouring & $1,25 \mathrm{ml} / 100 \ell$ & $10 \mathrm{ml}$ & & & & & 2.45 \\
\hline $\mathrm{CaCl}_{2}$ & $50 \mathrm{ml} / 100 \mathrm{l}$ & $50 \mathrm{ml}$ & & & & & 2.45 \\
\hline Rennet & $3 \mathrm{ml} / 100 t$ & $30 \mathrm{ml}$ & & 31 & & & 2.45 \\
\hline Cut & & & & 31 & 0,12 & 6,4 & 3.20 \\
\hline First rem & oval of whey & & & 31 & & & 3.35 \\
\hline Water ad & Ided & & & 31 & 0,11 & 6,4 & 3.45 \\
\hline Start hea & ting & & & 31 & & & 4.00 \\
\hline
\end{tabular}

Acid development: 1

2

3

End heating

36

4.40

Remove half of whey

36

0,12

$6.3 \quad 5.25$

Final whey removal

37

0,13

$6,1 \quad 5.55$

Cheddaring: start

end

Milling

Salting

Pressing

Yield: Number of cheeses:3

Moisture: $39,8 \quad \%$ Salt; 1,8
Mass: $10,9 \mathrm{~kg}$ Analyses: \% Fat: 30,2 pH: 5,09 


\section{CHEESE MANUFACTURING RECORD}

\section{CONTROL CHEESE B}

Type of Cheese: GOUDA

Date: $29 / 8 / 98$

Milk: \% Fat:

3.6

Acidity (\%) 0,15

Starter: Type

$\mathrm{CHN}_{22}$

\begin{tabular}{|c|c|c|c|c|c|c|}
\hline \multirow[t]{2}{*}{ Item/Action } & \multirow[t]{2}{*}{ Quantity } & \multirow[t]{2}{*}{$\%$ Fat } & \multirow[t]{2}{*}{ Temp $\left({ }^{\circ} \mathrm{C}\right)$} & \multicolumn{2}{|c|}{ Acidity } & \multirow[t]{2}{*}{ Time } \\
\hline & & & & $\%$ & $\mathrm{pH}$ & \\
\hline Milk & $100 \ell$ & 3.6 & & 0,15 & 6,6 & \\
\hline Starter $\quad 0,75 \%$ & $750 \mathrm{ml}$ & & & & & \\
\hline Cheese milk & $100 \ell$ & & 31 & 0.15 & 6,6 & 12.30 \\
\hline Colouring $1,25 \mathrm{ml} / 100 \ell$ & $10 \mathrm{ml}$ & & 31 & & & 12.30 \\
\hline $50 \mathrm{ml} / 100 \ell$ & $50 \mathrm{ml}$ & & 31 & & & 12.30 \\
\hline Rennet $3 \mathrm{ml} / 100 \ell$ & $30 \mathrm{ml}$ & & 31 & & & 12.30 \\
\hline Cut & & & 30,5 & 0,12 & 6,5 & 1.30 \\
\hline First removal of whey & & & 30,6 & & & 2.15 \\
\hline Water added & & & 30 & 0.10 & 6,5 & 2.30 \\
\hline Start heating & & & 30 & & & 2.25 \\
\hline
\end{tabular}

Acid development: 1

End heating

Remove half of whey

37,2

0,11

$6,3 \quad 3,55$

Final whey removal

36

0,13

$6,11 \quad 4.45$

Cheddaring: start

end

Milling

Salting

Pressing

Yield: Number of cheeses: 3

Mass: $10,936 \mathrm{~kg}$

Analyses: $\quad \%$ Fat: $31,2 \quad$ Moisture: $41,0 \quad \%$ Salt: $1,98 \quad \mathrm{pH}: 5,08$ 


\section{CHEESE MANUFACTURING RECORD}

EXPERIMENTAL CHEESE B

Type of Cheese: GOUDA

Date: $29 / 8 / 98$

Milk: \% Fat:

3.6

Acidity (\%) 0,15

Starter: Type

$\mathrm{CHN}_{22}$

\begin{tabular}{|c|c|c|c|c|c|c|c|}
\hline \multicolumn{2}{|c|}{ Item/Action } & \multirow[t]{2}{*}{ Quantity } & \multirow[t]{2}{*}{$\%$ Fat } & \multirow[t]{2}{*}{ Temp $\left({ }^{\circ} \mathrm{C}\right)$} & \multicolumn{2}{|c|}{ Acidity } & \multirow[b]{2}{*}{ Time } \\
\hline & Time & & & & $\%$ & $\mathrm{pH}$ & \\
\hline Milk & & $100 \ell$ & 3,6 & & 0,15 & 6,6 & \\
\hline Starter & $0,75 \%$ & $750 \mathrm{ml}$ & & & & & \\
\hline \multicolumn{2}{|c|}{ Cheese milk } & $100 \ell$ & & 30,8 & 0.15 & 6.6 & 1.25 \\
\hline Colouring & $\mathrm{g} 1,25 \mathrm{ml} / 100 \mathrm{l}$ & $10 \mathrm{ml}$ & & 30,8 & & & 1.25 \\
\hline $\mathrm{CaCl}_{2}$ & $50 \mathrm{ml} / 100 \mathrm{l}$ & $50 \mathrm{ml}$ & & 30,8 & & & 1.25 \\
\hline Rennet & $3 \mathrm{ml} / 100 \ell$ & $30 \mathrm{ml}$ & & 30,8 & & & 1.25 \\
\hline Cut & & & & 30,3 & 0,11 & 6,4 & 2.20 \\
\hline \multicolumn{2}{|c|}{ First removal of whey } & & & 30,3 & & & 2.45 \\
\hline \multicolumn{2}{|c|}{ Water added } & & & 30,1 & 0,10 & 6.4 & 2.50 \\
\hline \multicolumn{2}{|c|}{ Start heating } & & & 30,1 & & & 2.55 \\
\hline
\end{tabular}

Acid development: 1

3

End heating

Remove half of whey

Final whey removal

Cheddaring: start

end
37,6

37

37
3.00

0,10

$6,3 \quad 3.35$

0,13

$6,15 \quad 3.55$

Milling

Salting

Pressing

Yield: Number of cheeses: 2

Mass: $10,938 \mathrm{~kg}$

Analyses:\% Fat: 31,6

Moisture: $40,9 \quad \%$ Salt: $2,0 \quad$ pH: 5,05 


\section{CHEESE MANUFACTURING RECORD}

CONTROL CHEESE C

Type of Cheese: GOUDA

Date: $1 / 9 / 98$

Milk: \% Fat:

3.6

Acidity $(\%) 0,15$

Starter: Type

$\mathrm{CHN}_{22}$

\begin{tabular}{lcccc}
\hline \multirow{2}{*}{ Item/Action } & Quantity \% Fat & $\begin{array}{c}\text { Temp }\left({ }^{\circ} \mathrm{C}\right) \\
\text { Acidity } \\
\%\end{array}$ & pH \\
\hline Milk $100 \ell$ & 3,6 & 0,15 & 6,67 \\
Starter $0,75 \%$ & $750 \mathrm{ml}$ & &
\end{tabular}

Cheese milk

Colouring $1,25 \mathrm{ml} / 100$ l

$\mathrm{CaCl}_{2} \quad 50 \mathrm{ml} / 100 \ell$

Rennet $3 \mathrm{ml} / 100 \ell$

Cut

0,12

$6.4 \quad 2.45$

First removal of whey

Water added

0.10

$6.4 \quad 3.35$

Start heating 30

Acid development: 1

\section{2 \\ 3}

End heating 36

4.40

Remove half of whey

Final whey removal

Cheddaring: start

end

Milling

Salting

Pressing

Yield: Number of cheeses:3

Mass: $10,9 \mathrm{~kg}$

Analyses: $\quad \%$ Fat: $31 \quad$ Moisture: $40,8 \%$ Salt: 1,88 pH: 5,1 


\section{CHEESE MAINUFACTURING RECORD}

EXPERIMENTAL CHEESE C

Type of Cheese: GOUDA

Date: $1 / 9 / 98$

Milk: \% Fat:

3.6

Acidity $(\%) 0,15$

Starter: Type $\mathrm{CHN}_{22}$

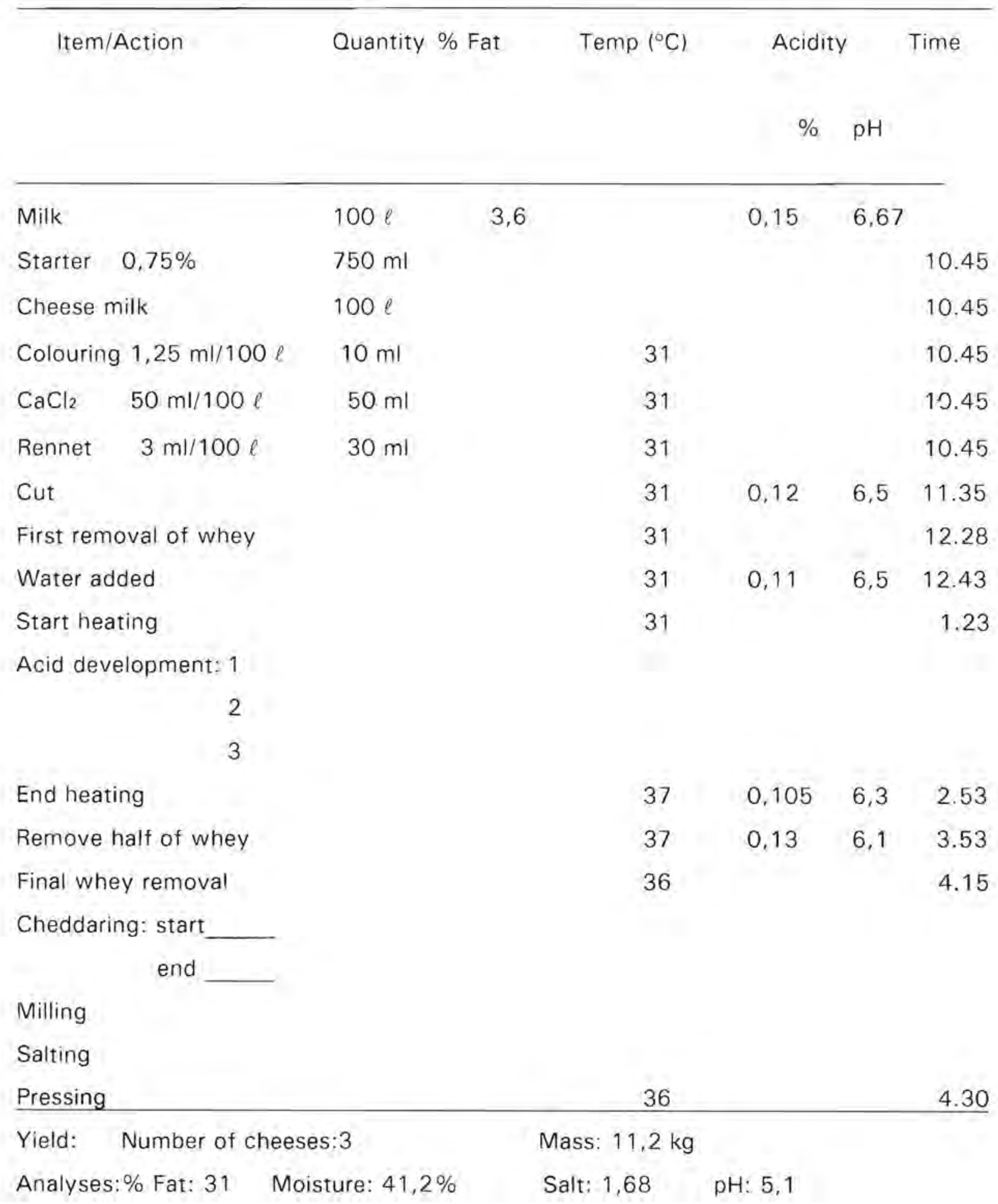

